\title{
$\alpha$-Keto amides as precursors to heterocycles-generation and cycloaddition reactions of piperazin-5-one nitrones
}

\author{
Frances Heaney, ${ }^{* a}$ Julie Fenlon, ${ }^{b}$ Patrick McArdle ${ }^{b}$ and Desmond Cunningham ${ }^{b}$ \\ ${ }^{a}$ Department of Chemistry, The National University of Ireland, Maynooth \\ ${ }^{b}$ Department of Chemistry, The National University of Ireland, Galway
}

Received 5th November 2002, Accepted 7th February 2003

First published as an Advance Article on the web 10th March 2003

$\alpha$-Keto amides $\mathbf{1 0 a}, \mathbf{b}$, formed from reaction of pyruvic or benzoylformic acid with allyl amine are found to present as single rotameric forms whilst their tertiary amido analogues $\mathbf{1 0 c}, \mathbf{d}$ present as two rotamers in solution at $\mathrm{rt}$. The hydroxyimino derivatives $\mathbf{8}$ share the conformational characteristics of their parents. The geometrical make-up of the new $\alpha$-amidooximes is seen to depend on the structure of the starting acid and on the degree of substitution of the amido group. The oxime 8a derived from pyruvic acid and allyl amine is formed solely as the $(E)$-isomer whilst its tertiary amido analogue $\mathbf{8 c}$ is formed as both $(E)$ - and $(Z)$-isomers. Oximes derived from benzoylformic acid have the opposite selectivity with both geometrical isomers forming from the secondary amide $\mathbf{8 b}$ and only the $(Z)$ )-isomer from the tertiary amide $\mathbf{8 d}$. With the exception of $\mathbf{8 b}$ all oximes were configurationally stable with $(Z)$-isomers reacting to form isoxazolopyrrolidinones 11 - compounds with a relatively rare bicyclic nucleus and $(E)$-isomers cyclising to piperazin-5-one nitrones 1 - ketopiperazine $N$-oxides have to date only appeared once in the literature. New nitrones were trapped with phenyl vinyl sulfone, dimethyl acetylenedicarboxylate and methyl propiolate yielding isoxazolidine and isoxazoline fused piperazinones 13,15,21 and 22. Cycloadducts from dimethyl acetylenedicarboxylate and $\mathbf{8 a}, \mathbf{b}$ are thermally labile and their rearrangement provides a novel route to pyrrolopiperazinones $\mathbf{1 6}$. The structure of a representative isoxazolopyrrolidinone, 11c, and a 2,3-dihydroisoxazoline fused piperazinone, $\mathbf{2 1 b}$, are unambiguously solved following x-ray structural analysis.

\section{Introduction}

Piperazin-5-one nitrones, $\mathbf{1}$, are thought to be promising scaffolds for the construction of molecules of biological significance $^{1,2}$ however the dipoles themselves and their cycloaddition products are relatively rare. There is only one reported example of a ketopiperazine nitrone in the literature, Bernotas and Adams have prepared $\mathbf{2}$ by oxidation of the corresponding piperazinone, and found it to cycloadd to simple dipolarophiles. ${ }^{2}$ Structurally related dipoles include the 5,6-dehydro analogues $\mathbf{3}$ and $\mathbf{4}$, the former results from an intermolecular condensation between glyoxal and (hydroxyamino)acetamide ${ }^{3}$ whilst the latter arises from a thiolate mediated cyclisation of an $O$-protected amidooxime ester. ${ }^{4}$ Tetrahydropyrazine $\mathrm{N}$-oxides have been formed by oxidation of $N$-hydroxypiperazines and their cycloadditions studied. ${ }^{5,6}$ We have reported that $\alpha$-keto esters $\mathbf{5 a}$ serve as precursors to nitrones with their $(E)$-alkenyl oxime derivatives $(E)$-5b cyclising to oxazin-6-one nitrones $\mathbf{6}$ whilst their $(Z)$-isomers, $(Z)$-5b follow an IOOC sequence (intramolecular oxime olefin cycloaddition) to yield isoxazolofuranones 7. ${ }^{7,8}$ We propose that piperazin-5-one nitrones $\mathbf{1}$ may be considered as aza analogues of $\mathbf{6}$ and in this paper we report, for the first time, generation of cyclic $\alpha$-amido nitrones by cyclisation of amido alkenyl oximes.

\section{Results and discussion}

The three step synthetic route to the oximes $\mathbf{8}$ involved generation of the acid chlorides of pyruvic and benzoylformic acid, amidation and finally oximation, Scheme 1. Generation of acyclic amido nitrones from $\alpha$-amido oximes has some precedent. Reaction between diazomethane and $\alpha$-oximinoketones has been shown to afford $N$ - or $O$-methylated derivatives where the product distribution bears some relationship to the geometry of the starting oxime. ${ }^{9}$ Imidazolinone nitrones result as the condensation product from reaction of cyclohexanone with primary amido oximes. ${ }^{10}$

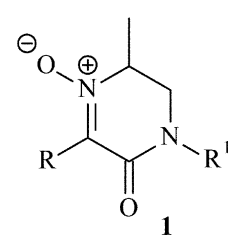<smiles>O=C1C=C([O-])[N+]([O-])CC1</smiles><smiles></smiles>

$$
\begin{aligned}
& \text { a. } R=M e, R^{1}=H \\
& \text { b. } R=P h, R^{1}=H \\
& \text { c. } R=R^{1}=M e \\
& \text { d. } R=P h, R^{1}=M e
\end{aligned}
$$<smiles>[R]Cc1[nH]c(=O)c(CC(C)C)[n+]([O-])c1OC</smiles><smiles>[R]C(=[X])C(=O)OC([R])C=C</smiles><smiles>[R]C1=[N+]([O-])C(C)C([R])OC1=O</smiles>

6

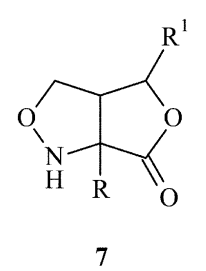

Acid chloride formation was most effectively achieved employing $\alpha, \alpha$-dichloromethyl methyl ether as chlorinating agent. ${ }^{11}$ The acid chlorides, 9 used without further purification, were each amidated in turn with allyl amine and with $N$-methyl allyl amine. Whilst the crude yields of the $N$-monosubstituted amides, 10a,b, as judged from the ${ }^{1} \mathrm{H}$ NMR spectra of the crude mixtures, were good much material was sacrificed during efforts 
<smiles>[R]C(=O)C(=O)C(=O)Cl</smiles>

9

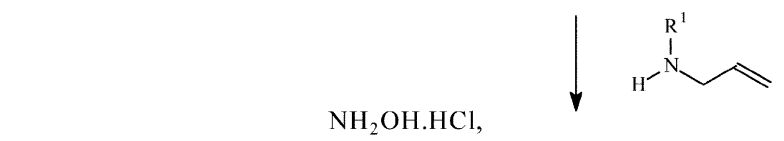<smiles>[R]C(=NO)C(=O)N([R])CC=C</smiles>

8 a. $\mathrm{R}=\mathrm{Me}, \mathrm{R}^{1}=\mathrm{H}$

b. $\mathrm{R}=\mathrm{Ph}, \mathrm{R}^{1}=\mathrm{H}$

c. $\mathrm{R}=\mathrm{R}^{1}=\mathrm{Me}$

d. $R=P h, R^{1}=M e$

Scheme 1

to purify by vacuum distillation, accordingly the $N, N$-disubstituted amides 10c,d were not subjected to purification. ${ }^{1} \mathrm{H}$ NMR spectral data for the tertiary amides show a doubled signal set indicating that in solution $\left[\mathrm{CDCl}_{3}, \mathrm{rt}\right]$ isomerisation is occurring about the tertiary amide bond [rotamer ratios $1: 1.4(\mathrm{R}=\mathrm{Me})$ and $1: 1.1(\mathrm{R}=\mathrm{Ph})]$. The secondary amides present as a single conformer.

Oximation was achieved under standard conditions, oxime 8a was obtained solely as the $(E)$-isomer. However, both geometrical isomers of $\mathbf{8 b}$ were present, $(E)-\mathbf{8 b}$ and $(Z)-\mathbf{8 b}$, found in a $2: 1$ ratio, were inseparable by flash column chromatography. A single rotamer was observed in the ${ }^{1} \mathrm{H}$ NMR spectrum for each geometrical isomer. The multiplicity of the ${ }^{1} \mathrm{H}$ NMR signal representing the allylic protons of the $\alpha$-oxo and $\alpha$-hydroxyimino secondary amides $\mathbf{1 0 a}, \mathbf{b}$ and $\mathbf{8 a}, \mathbf{b}$ is indicative of coupling between these protons and the $\mathrm{NH}$ proton. Significantly attempts to effect $H-D$ exchange for the oxime $8 \mathbf{a}\left(\mathrm{D}_{2} \mathrm{O}\right.$ shake) resulted, not in elimination of the $\mathrm{NH}$ and $\mathrm{OH}$ signals from the ${ }^{1} \mathrm{H}$ NMR spectrum but rather in a $50 \%$ reduction in the relative size of the signals representing each of these protons. We consider effective intramolecular $\mathrm{H}$-bonding to be responsible for the slow proton exchange. ${ }^{12}$

Oximation of the $\alpha$-oxo functionality of the tertiary amides furnished two geometrical isomers in the case of the pyruvic acid derivative, i.e. $(E)$ - and $(Z)-8 c$ whilst only the $(Z)$-isomer formed from the benzoylformic acid derivative, i.e. $(Z)-8 d$. Each of these oximes, like their $\alpha$-keto precursors, displayed evidence in their ${ }^{1} \mathrm{H}$ NMR spectra for the existence of two conformers differing in the rotameric state of the tertiary amide bond [e.g. the ${ }^{13} \mathrm{C}$ NMR spectrum of $(E)-8 \mathrm{c}$ exhibits $\mathrm{CH}_{3}$ signals at 12.08 and $12.25 \mathrm{ppm}$ whilst the corresponding carbon atom of $(Z)-8 \mathrm{c}$ resonates at 16.88 and $17.26^{13}$ ]. Rotamer ratios for the oximes are as follows: $(E)-8 \mathrm{c} 1: 1.2 ;(Z)-8 \mathbf{c} 1: 1$ and $(Z)-8 d 1: 1.2$.

The $\alpha$-keto- and hydroxyiminoamides, $\mathbf{1 0 , 8}$, have four conformational possibilities as sketched in Fig. 1. The carbonyl groups can have a syn or anti arrangement and the amide group may adopt the cis- or trans-rotameric state. With reference to Bach and co-workers findings for the torsional barriers in $N, N$-disubstituted $\alpha$-keto amides ${ }^{14}$ we propose that only those conformers having anti displacement of the carbonyl groups need to be considered, i.e. A and B, Fig. 1. Further, we postulate that in the case of the secondary amides, 10a,b the possibility for intramolecular $\mathrm{H}$-bonding as well as the minimised steric clashes should cause the anti-cis conformer, $\mathbf{A}$, to be of lower energy than the alternative trans isomer, $\mathbf{B}$, thus accounting for the presence of a single rotameric state for the $N$-monosubstituted amides. With little to choose between the steric demands of a methyl and an allyl group, coupled to<smiles>[R]C([X])C([O-])=[N+]([R])CC=C</smiles>

A anti-cis<smiles>[X]C([R])=C([O-])[N+]([R])CC=C</smiles>

C syn-cis<smiles>[X]C([R])=C([O-])[N+]([R])CC=C</smiles>

B anti-trans<smiles>[X]C([R])=C([O-])[N+]([R])CC=C</smiles>

D syn-trans
Fig. 1

the fact that H-bonding is no longer feasible, it is likely that the anti-cis and anti-trans conformers of the tertiary amides $\mathbf{1 0 c}, \mathbf{d}$ are close in energy, accordingly two rotameric forms are observed in solution. Whilst the $(E)$ - and $(Z)$-isomers of the oxime derivatives, $\mathbf{8}$, present a greater range of $\mathrm{H}$-bonding opportunities [5-and/or 6-rings] from their keto parents it is likely that the same factors operate to control the number of rotameric forms which present.

Variable temperature ${ }^{1} \mathrm{H}$ NMR spectra acquired for the tertiary amide oxime $(E)-8 \mathrm{c}$ over the range -50 to $+50{ }^{\circ} \mathrm{C}$ show evidence for signal coalescence, most obvious for the methyl signals. A significant change in the appearance of the $\mathrm{OH}$ resonance signal is also noted over this temperature range $\left[-50{ }^{\circ} \mathrm{C}\right.$ two distinct resonances, $\sim 10.60$ and $10.65 \mathrm{ppm},+50{ }^{\circ} \mathrm{C}$ one broad signal $\sim 9 \mathrm{ppm}]$. This upfield shift is consistient with a decrease in $\mathrm{H}$-bonding potential at higher probe temperature

Following heating in boiling xylene the oxime $(E)-8$ a cyclised to the piperazin-5-one nitrone 1a which was isolated in $65 \%$ yield. It was anticipated that, though inseparable by column chromatography, the isomeric oximes $\mathbf{8 b}$ would be differentiated by their preferred mode of reactivity. Thus, as $\mathbf{5 b}$ the "ester" analogues of $\mathbf{8}$ are conformationally stable with the $(E)$-isomer cyclising to oxazinone nitrones and the $(Z)$-isomer yielding fused bicyclic $\mathrm{NH}$-isoxazolidines it had been expected that both the piperazinone nitrone $\mathbf{1 b}$ and the isoxazolopyrrolidinone 11a would result from thermal treatment of the mixture of oximes. However, only the cyclic nitrone was isolated from the reaction mixture $(63 \%)$. We understand this result to mean that isomerisation $[(Z)-(E)]$ of the geometrical oximes $\mathbf{8 b}$ is possible under the reaction conditions and that if bicycle formation from the $(Z)$-oxime is, to any extent, competing with geometrical isomerisation it must be that formation of the bicycle 11a is reversible and that the equilibrium is shifted entirely towards the thermodynamically more stable 6-membered cyclic nitrone 1b [Fig. 2].

Grigg and co-workers have recently reported a relationship between the ease of oxime isomerisation of a series of aryl aldoximes and their mode of reactivity, they conclude that the more electron rich the aryl substitutent the more facile the isomerisation. ${ }^{15}$ It could be postulated that the difference between the $\alpha$-ester $\mathbf{5 b}(\mathrm{R}=\mathrm{Ph})$ and $\alpha$-amido $\mathbf{8 b}$ oximes is simply electronic [with the ester group being more electron attracting than the amide ${ }^{16}$ ] or it could be that the H-bonding potential of the secondary amide of $\mathbf{8 b}$ has a differential influence on the $E_{\text {act }}$ of the various steps, viz oxime isomerisation, piperazin-5-one nitrone formation or bicycle formation.

The nitrones $\mathbf{1 a}, \mathbf{b}$, in common with their oxime and keto precursors, exhibit coupling in the ${ }^{1} \mathrm{H}$ NMR spectrum between the $N H$ proton and each of the protons of the adjacent methylene group, indeed for 1a decoupling the $N H$ signal caused the signals representing each of the methylenic protons to collapse from ddd to dd. 
<smiles>C=C=CC(=NO)C(=O)C(=NO)C(=O)NCC=C</smiles>

Fig. 2

The oximes furnished following reaction between the tertiary $\alpha$-keto amides 10c,d and hydroxylamine were of unexpected geometrical make up with the pyruvic acid substrate yielding both $(E)$ - and $(Z)$-isomers of $\mathbf{8 c}$ and the benzoylformic acid furnishing only $(Z)-8 d$. The finding goes against our previous observations that pyruvic acid derivatives oximate to furnish a single oxime isomer whilst benzoylformic acid derivatives yield both isomers. ${ }^{7,8}$ The presence of the $N$-methyl group on the substrates $10 \mathbf{c}, \mathbf{d}$ must promote formation of the $(Z)$-oxime isomer.

The oximes of $\mathbf{8 c}$ showed stereochemical integrity with $(E)-8 c$ cyclising to the nitrone $1 \mathbf{c}(63 \%)$ and $(Z)-8 c$ affording the $N H$ bicycle $\mathbf{1 1 b}(60 \%)$. Similarly the $(Z)$-oxime isomer $(Z)-8 d$ reacted to give only the $N H$ bicycle $11 \mathrm{c}(91 \%)$. It is thus apparent that $(Z)-(E)$-oxime isomerisation for the tertiary amido oximes 8c cannot compete with formation of the bicycle. This result would appear to suggest that the H-bonding capacity of the secondary amido oxime, $\mathbf{8 b}$, plays a pivotal role in permitting $(Z)-(E)$-geometrical isomerisation to be in effective competition with isoxazolopyrrolidinone formation.

The isoxazolopyrrolidinone bicyclic nucleus of $\mathbf{1 1}$ represents an unusual skeletal motif with just two examples from Akmanova's laboratory being found in the literature, thus intramolecular cycloaddition of in situ generated alkenyl amidonitrones has furnished $\mathbf{1 2}$ in moderate yield, Scheme $2 .{ }^{17}$

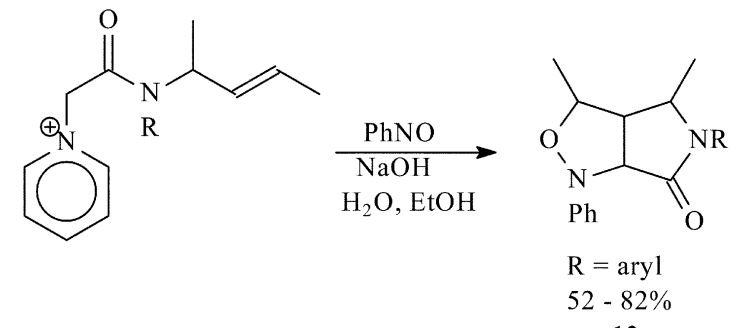

12

Scheme 2

The broad appearance of the signals representing the $3-\mathrm{H}$ protons in ${ }^{1} \mathrm{H}$ NMR spectral data for both $11 \mathrm{~b}$ and $11 \mathrm{c}$ when recorded at $\mathrm{rt}$ is indicative of isoxazolidine ring fluxion. In the case of $\mathbf{1 1 b}$ these signals sharpened significantly upon lowering probe temperature $\left[\mathrm{rt} \delta 3.96, \mathrm{~m}, 2 \mathrm{H} ;-40{ }^{\circ} \mathrm{C} \delta 3.92,1 \mathrm{H}\right.$, slightly (sl) br dd and $\delta 4.17,1 \mathrm{H}$, sl br dd] suggesting the $6 \mathrm{a}-\mathrm{Me}$ bicycle has one preferred conformation at low temperature. When ${ }^{1} \mathrm{H}$ NMR data for 11c was recorded below $\mathrm{rt}$ a broadening of all resonance signals was observed. This observation is in keeping with a slow rate of conformer inversion for 11c, in particular, at $-30{ }^{\circ} \mathrm{C}$ two $N M e$ signals become apparent, $\delta 2.84$ (major) and 2.94 (minor). Thus, the $C$-6a substituent plays a key role in determining the activation energy for conformer interconver- sion, with a phenyl group in this position the barrier to inversion is lowered with respect to its methyl substituented analogus.

Crystals of 11c crystallised from benzene-petroleum spirit. The crystals contained 1.5 molecules of hydroquinone per asymmetric unit (hydroquinone was added to prevent solvent decomposition during thermal activation of 8d). The crystal structure was determined by X-ray diffraction. ${ }^{18-20}$ An ORTEX representation of the molecules of 11c in the crystal, Fig. 3, confirms cis fusion of the 5,5-bicycle. The $\mathrm{NH}$ and $\mathrm{C}=\mathrm{O}$ of 11c are both involved in $\mathrm{H}$-bonding to the hydroquinones. Each molecule of 11c has a full and a half molecule of hydroquinone associated with it. The complete hydroquinone oxygens are $O-21$ and $O-22$ and the half hydroquinone contains $O-26$. The latter is completed across an inversion centre. A complex hydrogen bonded network links the hydroquinone and 11c molecules. Each molecule of 11c is linked to a neighbouring molecule of 11c through a bridging hydrogen bonded hydroquinone $(O-21-O-22)$. The hydrogen bonding results in a close contact $O-21 \cdots O-13$ of $2.71 \AA$ at one end and close contacts of $O-22 \cdots N-1$ and $O-22 \cdots O-13$ of 2.88 and $3.20 \AA$ respectively at the other end. The net result is to generate a helical chain which propagates parallel to the b-axis. As a result of the spiralling effect of the chain, neighbouring quinoline molecules become involved in (relatively weak) aromatic $\pi$-interactions. $O-22$ of the hydroquinone is also involved in hydrogen bonding with $O-26$ resulting in an $O-22 \cdots O-26$ close contact of $2.80 \AA$. This is the only type of hydrogen bonding interaction involving $O-26$ hydroquinone. All $O-22 \cdots O-26$ vectors within the lattice are parallel but along each chain they alternate with relative orientations of $180^{\circ}$. The net result of these two orientations and the centrosymmetric nature of the hydroquinone linking the chains is to link helical chains into a two dimensional network.

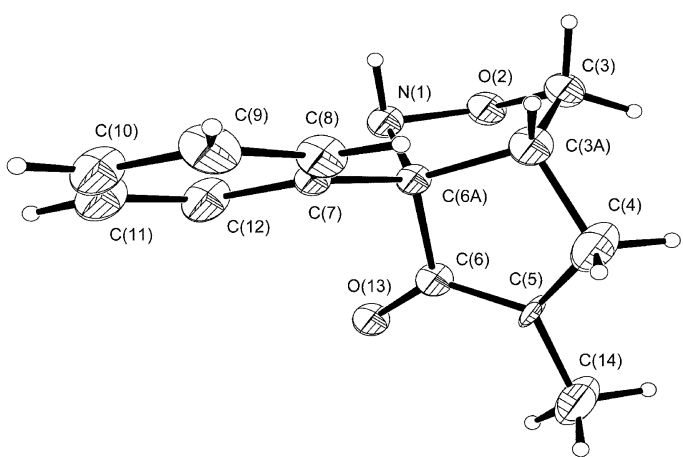

Fig. 3 ORTEX representation of 11c.

NOEDS results for $\mathbf{1 1 b}$ indicate enhancements on the signals representing the $6 \mathrm{a}-\mathrm{Me}$ protons $(3 \%)$ and the $3 \mathrm{a}-\mathrm{H}(13 \%)$ following irradiation of the $4 \mathrm{a}-\mathrm{H}$ thus indicating that it shares the stereochemical features of its phenyl analogue.

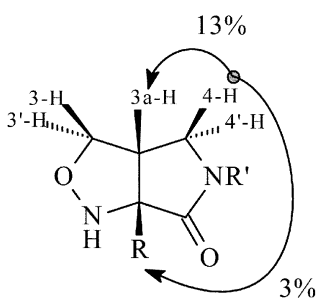

11

$$
\begin{aligned}
& \text { a. } R=P h, R^{1}=H \\
& \text { b. } R=R^{1}=M e \\
& \text { c. } R=P h, R^{1}=M e \\
& \text { nOe data shown for } \mathbf{1 1 b}
\end{aligned}
$$


Table 1 Selected ${ }^{1} \mathrm{H}$ NMR data for cycloadducts $\mathbf{1 3}$

\begin{tabular}{llllll}
\hline Adduct & 7-H & 7-Me & 6a-H & 6b-H & 2-H \\
\hline 13a & 3.48 & 1.28 & $3.18(13.1,4.5 \& 4.3)$ & $3.14\left(\mathrm{~m}^{a}\right)$ & $5.04(7.7 \& 7.7)$ \\
13b & 3.55 & 1.30 & $3.09\left(\mathrm{~m}^{a}\right)$ & $3.22(12.2 \& 10.7)$ & $5.05(8.3 \& 8.3)$ \\
13c & 3.71 & 1.39 & $3.21(\mathrm{~m})$ & $3.21(\mathrm{~m})$ & $4.68(7.1 \& 9.5)$
\end{tabular}

${ }^{a}$ multiplet signal representing $6 \mathrm{a} / \mathrm{b}-\mathrm{H}$ and $3 \mathrm{~b}-\mathrm{H}$.

In search of isoxazolo-fused ketopiperazines, of which there has just been one literature report to date, ${ }^{2}$ the nitrones 1 were treated with electron poor olefins and acetylenes. Phenyl vinyl sulfone was chosen as a representative olefinic dipolarophile. Following heating in boiling toluene each of the three dipoles reacted with a high degree of selectivity and only one cycloaddition product could be isolated following purification by flash column chromatography. Reaction was selective for formation of an isoxazolidine ring carrying the substituent on the 5-position. Attempts to assign relative stereochemistry to these adducts by analysis of NOEDS data are incomplete, thus for 13a an $11 \%$ enhancement on $2-\mathrm{H}$ following irradiation of $3 \mathrm{a}-\mathrm{H}$ and a $1.5 \%$ enhancement on $3 \mathrm{a}-\mathrm{Me}$ after irradiation of $3 \mathrm{a}-\mathrm{H}$ indicates that the phenylsulfonyl group and the $3 \mathrm{a}-\mathrm{Me}$ are on opposite faces of the bicyclic structure. We are not in a position to comment directly on the spatial relationship between these protons and the $C-7 \mathrm{Me}$ as no significant cross ring nuclear Overhausser effects are observed. A $1.7 \%$ NOE observed on $3 \mathrm{a}-\mathrm{Me}$ following irradiation of the $2-\mathrm{H}$ signal of $\mathbf{1 3 b}$ and an $11 \%$ enhancement on $2-\mathrm{H}$ after irradiation of $3 \mathrm{a}-\mathrm{H}$, together with the similarity between the ${ }^{1} \mathrm{H}$ NMR spectral data $[\delta$ values and ${ }^{3} J$, Table 1] for 13a and 13b suggest that the $C$-3a methyl substituted adducts have the same relative stereochemistry. For the $C$-3a phenyl adduct $13 \mathrm{c}$ a cross ring enhancement on $3 \mathrm{~b}-\mathrm{H}$ $(5 \%)$ upon irradiation of the $7-\mathrm{H}$ signal coupled with a $9 \%$ enhancement on $2-\mathrm{H}$ following irradiation of $3 \mathrm{a}-\mathrm{H}$ indicates that the $C-7 \mathrm{Me}$ and the phenylsulfonyl group are on opposite faces of the molecule. No enhancements were observed on the $3 \mathrm{a}-\mathrm{Ph}$ protons so prohibiting assignment of relative stereochemistry at the ring junction. One characteristic feature of the NOEDS for all three adducts is a negative NOE on $3 \mathrm{a}-\mathrm{H}$ following irradiation of 7-H (and vice versa), e.g. for 13a irradiation of $7-\mathrm{H}$ caused a $-0.8 \%$ enhancement on $3 \mathrm{a}-\mathrm{H}$ whilst a $-2.8 \%$ enhancement was observed on $7-\mathrm{H}$ when $3 \mathrm{a}-\mathrm{H}$ was irradiated. On the basis of this unifying observation we propose that 13a, 13b and 13c have the same relative stereochemistry and so we combine the NOEDS data for the individual adducts to propose the structure shown in the drawing, Fig. 4 . The relative stereochemistry of $\mathbf{1 3}$ indicates that the cycloadducts were formed via an endo approach of the dipolarophile to the least hindered face of the nitrone, i.e. from the face opposite the $C-2$ methyl substituent.

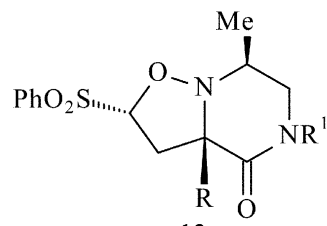

13

Fig. 4

The signals in the ${ }^{1} \mathrm{H}$ and ${ }^{13} \mathrm{C}$ NMR spectra (rt) of the three phenyl vinyl sulfone adducts are sharp suggesting either the adducts present as a single conformational form or that the rate of inversion is on a par with the timescale of the NMR experiment. Ali's group report that structurally related isoxazolofused piperazines, e.g. 14, Fig. 5, present as pairs of invertomers at rt. One presentation is the trans fused isomer $\mathbf{A}$ and the other presentation is a rapidly equilibrating pair of cis-fused

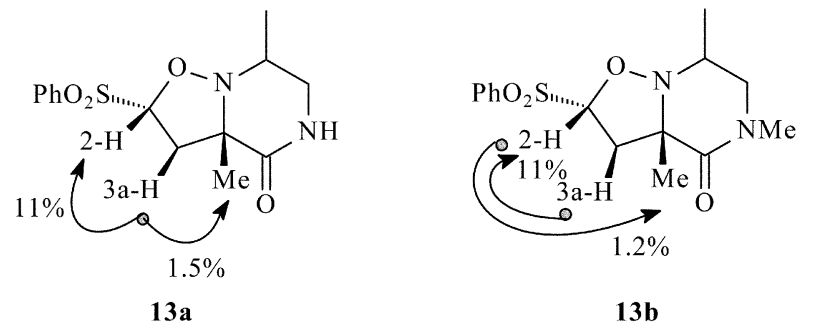

$13 \mathrm{a}$

$13 \mathrm{~b}$

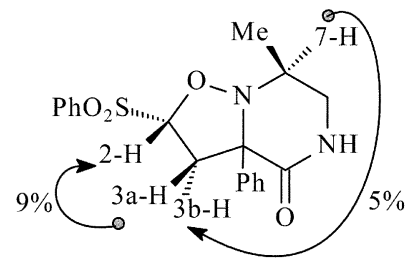

$13 \mathrm{c}$

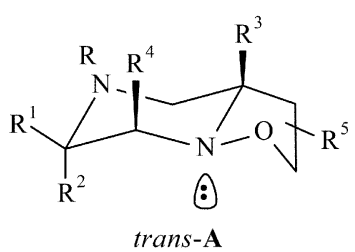

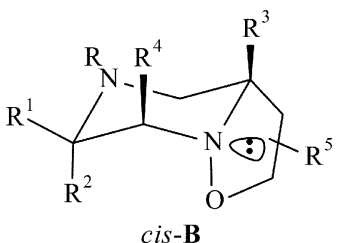

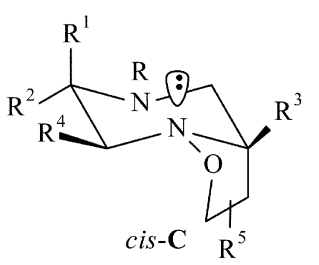

Fig. 5 For 13a-c $\mathrm{R}=\mathrm{H}, \mathrm{Me} ; \mathrm{R}^{1}, \mathrm{R}^{2}=(=\mathrm{O}) ; \mathrm{R}^{3}=\mathrm{Me} ; \mathrm{R}^{4}=\mathrm{Me}, \mathrm{Ph}$; $\mathrm{R}^{5}=\mathrm{SO}_{2} \mathrm{Ph}$ For Ali's compounds ${ }^{5} 14 \mathrm{R}=\mathrm{R}^{1}=\mathrm{R}^{2}=\mathrm{R}^{3}=\mathrm{R}^{4}=\mathrm{H}$; $\mathrm{R}^{5}=\mathrm{Ph}, \mathrm{Me} \mathrm{CO}_{2} \mathrm{Me}$.

conformers B and C. ${ }^{5}$ Adducts 13a-c differ from Ali's compounds both in their skeletal framework and in the extent of ring substitution; the former are 6-one analogues of $\mathbf{1 4}$ and are substituted at the $C-3$ a and $C-7$ positions. It is our belief that this substitution pattern conspires to force our adducts to present as a single conformational form. Thus both the trans-fused conformer $\mathbf{A}$ and the cis-conformer $\mathbf{B}$ suffer from 1,3-diaxial interactions. The second cis-conformer $\mathbf{C}$ (related to $\mathbf{B}$ by chair inversion) has the $C-7$ methyl and the $C$-3a substituent adopting the equatorial orientation - we believe this conformer to be the only viable presentation for adducts $\mathbf{1 3}$.

Reaction between the dipoles $\mathbf{1}$ and the acetylenic substrate dimethyl acetylenedicarboxylate, lead in all cases to one major cycloadduct, together with smaller amounts of other products. The $C$-Me secondary amido nitrone 1a reacted with dimethyl acetylenedicarboxylate (1.5 equivalents) in boiling $\mathrm{CHCl}_{3}(9 \mathrm{~h})$ to afford 15a in $63 \%$ yield. The tertiary amido analogue 1c furnished $\mathbf{1 5 b}$ in $67 \%$ yield after $24 \mathrm{~h}\left(\mathrm{CHCl}_{3}, 63{ }^{\circ} \mathrm{C}\right)$. The $C$-phenyl dipole $\mathbf{1 b}$ reacted after $40 \mathrm{~h}$ heating to yield $\mathbf{1 5 c}$ as the major adduct and its diastereomer $\mathbf{1 5} \mathbf{c}^{\prime}$, which could not be obtained pure, in a $6: 1$ ratio. All adducts failed to display cross ring nuclear Overhausser enhancements between the $C-7$ methyl and the $C$-3a substituent thus prohibiting comment on their relative stereochemistry. 


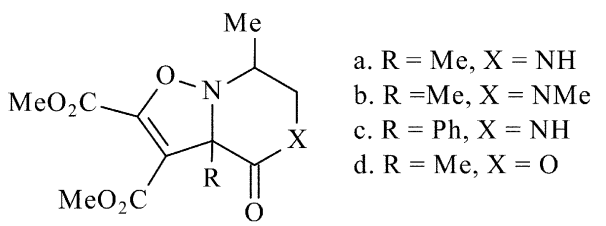

15

In the ${ }^{1} \mathrm{H}$ NMR spectrum of cycloadducts $\mathbf{1 5 a}$ and $\mathbf{1 3 a}, \mathbf{b}$ where distinct resonance signals are observed for $6 \mathrm{a}-\mathrm{H}$ and $6 \mathrm{~b}-\mathrm{H}$ it is evident that coupling occurs between the $\mathrm{NH}$ proton and only one of the adjacent methylene protons $-6 \mathrm{a}-\mathrm{H}$ the endo proton. In contrast, in the parent nitrones each of these protons couples to the $N H$ proton. A significant difference is also observed in the pattern of coupling between the methylene protons and the adjacent $7-\mathrm{H}$ proton in the nitrone $\mathbf{1}$ and cycloadduct $\mathbf{1 3 , 1 5}$ families. Thus for the cycloadducts the $\mathrm{cis}$ relationship between $7-\mathrm{H}$ and $6 \mathrm{a}-\mathrm{H}$ is borne out by a small $J$ value $(\sim 4 \mathrm{~Hz})$ whilst trans related protons $7-\mathrm{H}$ and $6 \mathrm{~b}-\mathrm{H}$ consisitently have a larger $J$ value $(\sim 10 \mathrm{~Hz})$. The magnitude of ${ }^{3} J_{6,7}$ has no diagnostic value for the nitrones e.g. for $1 c^{3} J_{6 a, 7} 5.4 \mathrm{~Hz}$ and ${ }^{3} J_{6 \mathrm{~b}, 7} 4.9 \mathrm{~Hz}$.

The $C$-3a methyl substituted primary cycloadducts $\mathbf{1 5 a}, \mathbf{b}$, like their oxa analogues ${ }^{21}$ were found to be thermally labile giving the pyrrolopiperazinones 16a,b after heating alone in $\mathrm{CHCl}_{3}$ (66 and $85 \%$ respectively). The rearrangement likely proceeds by a mechanism parallel to that previously suggested for the oxa analogue 15d. ${ }^{21}$ The pyrroloketopiperazine skeleton is found infrequently in the chemical literature, however it does occur naturally in the alkaloid peramine $17 .^{22}$ The marine metabolites longamide 18a, and hanishin, 18b, also have a 3,4dihydropyrrolopiperazinone framework. ${ }^{23}$ The most common synthetic route to the heterocyclic core of these molecules involves cyclisation of appropriately substituted pyrroles ${ }^{22-24}$ and one approach exploits a polyphosphoric acid induced Beckmann rearrangement, thus the 2,3-dihydropyrrolizine iminium salt 19 is a precursor to $20{ }^{25}$ The formation the dihydropyrrolopiperazinone ring system by rearrangement of other heterocyclic nuclei is hither to unreported, the high yield with which 16a,b can be obtained from the parent isoxazolopiperazinones 15a,b makes this route an attractive option.<smiles>[Y7]CC(C)n1c(C(C)=O)cc(C(C)=O)c1C(C)=O</smiles>

16<smiles>Cn1cc(CCCNC(=N)N)c2cccn2c1=O</smiles>

17

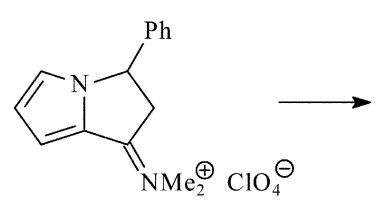

19

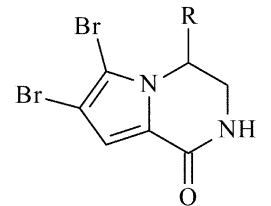

Longamide $\mathrm{R}=\mathrm{OH}$ Hanishin $\mathrm{R}=\mathrm{CH}_{2} \mathrm{CO}_{2} \mathrm{Et}$

18

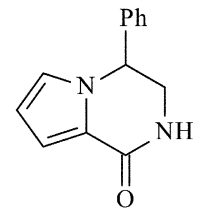

20
Methyl propiolate is a somewhat less reactive dipolarophile than dimethyl acetylenedicarboxylate and a five fold excess was employed to promote its cycloaddition to the secondary amido- nitrones. After one week at rt the products of reaction between 1a and methyl propiolate, analysed by ${ }^{1} \mathrm{H}$ NMR spectroscopy, were shown to comprise two major isomeric cycloadducts in a $1: 2.4$ ratio, small amounts of other adducts were also present. A pure sample of the 5-substituted isoxazoline, 21a, (22\%) was obtained following column chromatography, the 4-substituted isomer, 22a, $(52 \%)$ could not be obtained pure. It is easy to discriminate between the 4- and 5-substituted isoxazoline rings on the basis of the chemical shift of the $2-\mathrm{H} / 3-\mathrm{H}$ proton in the ${ }^{1} \mathrm{H}$ NMR spectrum $[\delta 7.39$ vs 6.08]. The deshielding effect of a proximate carbomethoxy group on the resonance of the $C-3 \mathrm{a}$ methyl protons is also noteworthy with 21a having this signal at $\delta 1.58$ whilst the signal representing the same protons appears at $\delta 1.73$ for its isomer 22a. At $\mathrm{rt}$ reaction between the phenyl substituted dipole 1b and methyl propiolate progressed more slowly, however, after $42 \mathrm{~h}$ heating in boiling $\mathrm{CHCl}_{3}$ the isomeric cycloadducts $\mathbf{2 1 b}, \mathbf{2 2} \mathbf{b}$ were furnished as major reaction products ( 31 and $36 \%$ respectively), there was also evidence for a small amount $(5 \%)$ of $\mathbf{2 2} \mathbf{b}^{\prime}$ a diastereomer of the 4-substituted adduct, minor amounts of other products were also present. As is the case with the regioisomers of the $C$-3a methyl analogue flash column chromatography furnished a pure sample of the 5-substituted isomer 21b but the 4-substituted isomer 22b could not be obtained pure. As for the saturated analogues the skeletal framework of the bicycles 15,21 and $\mathbf{2 2}$ did not leave the reading of their relative stereochemistry open to interpretation by NOEDS analysis.<smiles>[R]C1=CC(C(C)=O)ON2C(C)CNC(=O)C12[R]</smiles><smiles>[R]C1=CCON2C(C)CNC(=O)C12[R]</smiles>

$$
\begin{aligned}
& \text { a. } \mathrm{R}=\mathrm{Me} \\
& \text { b. } \mathrm{R}=\mathrm{Ph}
\end{aligned}
$$

A sample of $\mathbf{2 1 b}$, crystallised from diethyl ether-petroleum spirit provided crystals suitable for X-ray structure determination and the ORTEX representation of the structure is shown in Fig. 6. Analysis of the crystal data indicates $H$-bonded dimers in the lattice, a bit like the base pairs in DNA. The H-bond is between $O-19$ and $N-5$ and the distance between these atoms is $2.95 \AA$. The piperazinone ring is not very flat and on looking at the ORTEX drawing of the crystal structure it is unsatisfactory to describe the $C-3 \mathrm{~A} / C-7$ substituents simply as cis. We are tempted to conclude that the conformation adopted by the bicyclic nucleus of 21b explains the lack of any NOE between the cross ring groups despite their cis arrangement. Thus, taking the position of the carbon atom of the $C-7 \mathrm{Me}$ group as the crude averaged hydrogen atom position, the distances between this Me group and the $o$-hydrogen atoms on the phenyl ring are $C-20-H-104.32$ and $C-20-H-116.36 \AA$. These separations are sufficiently large to suggest that it may be unrealistic to expect any significant nuclear Overhausser enhancements between these protons even in the event that they have a cis relationship. The relative stereochemistry of $\mathbf{2 1 b}$ indicates that it results from a cycloaddition where the dipolarophile approached the nitrone on the least hindered face, i.e. the face opposite the $C$-2 methyl substituent.

\section{Conclusions}

In conclusion, terminally unsaturated $\alpha$-hydroxyiminoamides, prepared in a short reaction sequence from pyruvic or benzoylformic acid, have been demonstated to be valuable precursors for the generation of a diverse range of heterocycles. $(Z)$-Oxime isomers $8 \mathbf{c}, \mathbf{d}$ react exclusively by an IOOC reaction opening an 

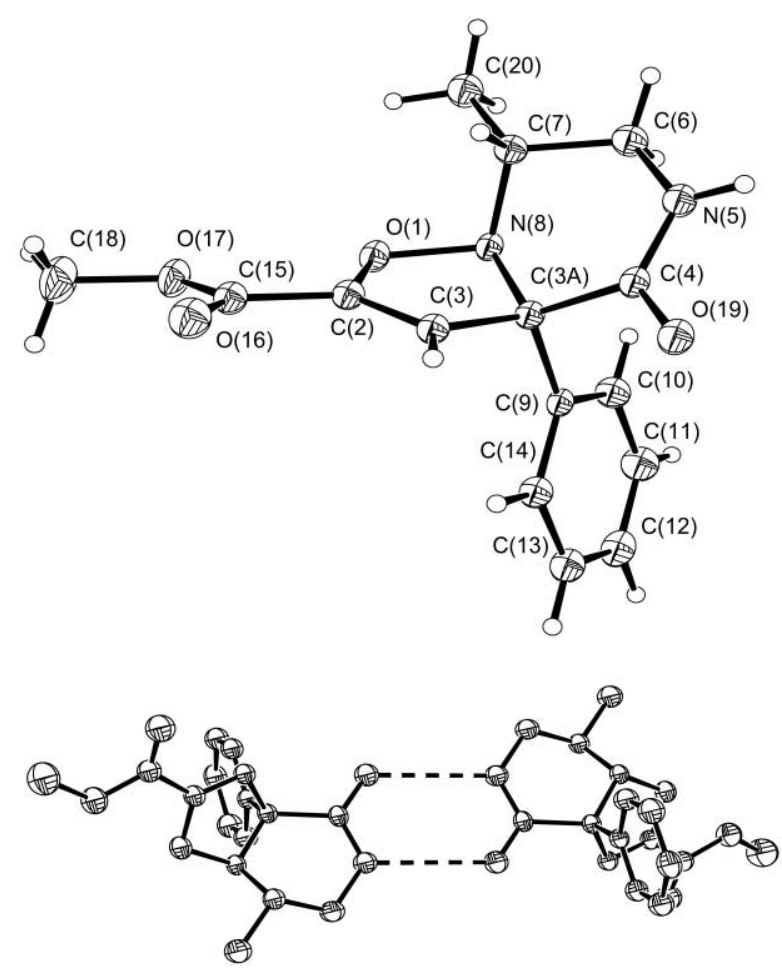

Fig. 6 ORTEX representation of $\mathbf{2 1 b}$. ORTEX representation of $\mathbf{2 1 b}$ showing $H$-bonded dimeric structure.

entrance to the relatively rare isoxazolopyrrolidinone framework. (E)-Oximes 8a,c react chemospecifically cyclising to novel heterocyclic piperazin-5-one nitrones. [3+2] Addition to the new nitrones provides isoxazolidine and isoxazoline fused bicycles. Rearrangement of the latter opens a viable route to pyrroloketopiperazines. We continue to explore further the synthetic potential of these reactions.

\section{Experimental}

Mps were determined on an Electrothermal melting point apparatus and are uncorrected. Elemental analyses were performed on a Perkin-Elmer model $240 \mathrm{CHN}$ analyser. IR spectra (nujol mull and liquid film) were measured on a Perkin Elmer 1600 series (FT) or a Perkin Elmer $983 \mathrm{G}$ spectrometer. $1 \mathrm{H}$ and 13C NMR spectra were recorded using a JOEL EX270 FT NMR spectrometer and a JOEL JNM-LA400 FT NMR spectrometer at probe temperatures with tetramethylsilane as internal reference and deuteriochloroform as solvent (unless otherwise stated), $J$ values are given in Hertz. DEPT-135 assignments are presented directly after individual ${ }^{13} \mathrm{C}$ resonance signals as $(+)\left(\mathrm{CH}\right.$ or $\left.\mathrm{CH}_{3}\right),(-)\left(\mathrm{CH}_{2}\right)$ or $(\mathrm{abs})$ (quaternary carbon atoms). Flash column chromatography was carried out on silica gel 60 (Merck 9385, 70-230 mesh) and analytical TLC plates were purchased from Merck. Samples were located by UV illumination using a portable Spectroline Hanovia lamp $(\lambda, 254 \mathrm{~nm})$ or by the use of iodine staining. Mass spectra were recorded on a Profile Kratos Analytical Instrument.

\section{2-Oxopropanoyl chloride 9a}

Pyruvic acid (10 g, $0.114 \mathrm{~mol})$ was placed in a $100 \mathrm{~cm}^{3}$ threenecked round bottomed flask with a condenser, an acid trap and a dropping funnel attached. The flask was placed under $\mathrm{N}_{2}$ and stirring initiated. $\alpha \alpha$-Dichloromethyl methyl ether $(13.06 \mathrm{~g}$, $0.114 \mathrm{~mol}$ ) was placed in the dropping funnel and the apparatus was left under $\mathrm{N}_{2}$ for $20 \mathrm{~min}$. The ether was added drop-wise whereupon evolution of $\mathrm{HCl}$ started. The mixture was heated to an oil bath temperature of $50{ }^{\circ} \mathrm{C}$ for $30 \mathrm{~min}$ and allowed to cool to rt. Methyl formate, a reaction by-product, was removed on a rotary evaporator (care was taken to ensure the water bath temperature did not exceed $20^{\circ} \mathrm{C}$ ) until a constant flask weight. The title compound $8.00 \mathrm{~g}, 66 \%$ was obtained as a pungent mobile yellow oil which was not purified further. $\delta_{\mathrm{H}}(400 \mathrm{MHz})$ $2.52\left(3 \mathrm{H}, \mathrm{s}, \mathrm{CH}_{3}\right)$.

\section{2-Oxo-2-phenylacetyl chloride 9b}

Reaction conducted according to the procedure outlined above on a scale employing benzoylformic acid $(6.0 \mathrm{~g}, 0.04 \mathrm{~mol})$. The title compound $(6.78 \mathrm{~g}, 100 \%)$, obtained as a pungent mobile yellow oil was not purified further; $\delta_{\mathrm{H}}(400 \mathrm{MHz}) 7.5(3 \mathrm{H}, \mathrm{m}$, $3 \times \operatorname{Ar} \mathrm{H}), 7.7(2 \mathrm{H}, \mathrm{m}, 2 \times \mathrm{ArH})$.

\section{N-Allyl-2-oxopropanamide 10a}

A suspension of allyl amine $(8.34 \mathrm{~g}, 0.146 \mathrm{~mol})$, sodium hydrogen carbonate $(12.26 \mathrm{~g}, 0.146 \mathrm{~mol})$ in anhydrous $\mathrm{CH}_{2} \mathrm{Cl}_{2}(115$ $\mathrm{cm}^{3}$ ) was stirred at $0{ }^{\circ} \mathrm{C}$. To the cooled suspension 2-oxopropanoyl chloride $9 \mathrm{a}$ ( $13.0 \mathrm{~g}, 0.122 \mathrm{~mol})$ was added drop-wise and the mixture was stirred at $\mathrm{rt}$ for $1 \mathrm{~h}$. The mixture was washed with water $\left(3 \times 100 \mathrm{~cm}^{3}\right)$, the organic layer was dried (anhydrous $\mathrm{Na}_{2} \mathrm{SO}_{4}$ ), filtered and concentrated, to afford crude product, $8.94 \mathrm{~g}, 58 \%$. Purification by distillation gave 10a, $4.32 \mathrm{~g}, 29 \%$, as a mobile, colourless, odourless oil $\left(36-38{ }^{\circ} \mathrm{C}\right.$; 0.16 Torr) (Found: $\mathrm{C}, 54.57 ; \mathrm{H}, 6.93 ; \mathrm{N}, 10.36 . \mathrm{C}_{6} \mathrm{H}_{9} \mathrm{NO}_{2}$ requires: $\mathrm{C}, 54.96 ; \mathrm{H}, 6.87 ; \mathrm{N}, 10.68 \%) ; \delta_{\mathrm{H}}(400 \mathrm{MHz}) 2.40(3 \mathrm{H}$, $\left.\mathrm{s}, \mathrm{CH}_{3}\right), 3.86\left(2 \mathrm{H}, \mathrm{m},-\mathrm{CH}_{2}-\right), 5.11\left(2 \mathrm{H}, \mathrm{m},=\mathrm{CH}_{2}\right), 5.76(1 \mathrm{H}, \mathrm{m}$, $=\mathrm{CH}), 7.36(1 \mathrm{H}$, br s, N-H $) ; \delta_{\mathrm{C}}(100 \mathrm{MHz}) 24.10\left(\mathrm{CH}_{3}\right), 41.25$ $\left(-\mathrm{CH}_{2}-\right), 116.44\left(=\mathrm{CH}_{2}\right), 132.75(=\mathrm{CH}), 159.79(\mathrm{C}=\mathrm{O}$ amide $)$, $196.61(\mathrm{C}=\mathrm{O}) ; v_{\max } / \mathrm{cm}^{-1} 3332(\mathrm{~N}-\mathrm{H}), 1723(\mathrm{C}=\mathrm{O}), 1681(\mathrm{C}=\mathrm{O}$ amide).

\section{$\mathrm{N}$-Allyl-2-oxo-2-phenylacetamide 10b}

A suspension of allyl amine $(2.03 \mathrm{~g}, 35.6 \mathrm{mmol})$, sodium hydrogen carbonate $(2.99 \mathrm{~g}, 35.6 \mathrm{mmol})$ and anhydrous $\mathrm{CH}_{2} \mathrm{Cl}_{2}$ $\left(30 \mathrm{~cm}^{3}\right)$ was stirred at $0{ }^{\circ} \mathrm{C}$. To the cooled suspension 2-oxo-2phenylacetyl chloride 9b $(5.5 \mathrm{~g}, 32.6 \mathrm{mmol})$ was added dropwise and the mixture was stirred at $\mathrm{rt}$ for $1 \mathrm{~h}$. The mixture was washed with water $\left(3 \times 10 \mathrm{~cm}^{3}\right)$, the organic layer was dried (anhydrous $\mathrm{Na}_{2} \mathrm{SO}_{4}$ ), filtered and concentrated, to afford the crude product $5.61 \mathrm{~g}, 91 \%$, as a low melting solid. Purified by distillation $\left(89-93{ }^{\circ} \mathrm{C}, 0.03 \mathrm{~mm} \mathrm{Hg}\right.$ ), gave $10 \mathrm{~b}$ which solidified on standing, $2.61 \mathrm{~g}, 42 \%, \mathrm{mp} 56-58{ }^{\circ} \mathrm{C}$ (from $\mathrm{CHCl}_{3}$ ) (Found: C, 70.02; H, 5.79; N, 6.94. $\mathrm{C}_{11} \mathrm{H}_{11} \mathrm{O}_{2} \mathrm{~N}$ requires: $\mathrm{C}, 69.84 ; \mathrm{H}$, 5.82; N, 7.41\%); $\delta_{\mathrm{H}}(400 \mathrm{MHz}) 3.83\left(2 \mathrm{H}, \mathrm{m}, \mathrm{CH}_{2}\right), 5.05(2 \mathrm{H}, \mathrm{m}$, $\left.=\mathrm{CH}_{2}\right), 5.72(1 \mathrm{H}, \mathrm{m},-\mathrm{CH}=), 7.27(2 \mathrm{H}, o-\mathrm{ArH}), 7.42(1 \mathrm{H}, \mathrm{m}$, $p$-ArH $), 8.11(2 \mathrm{H}, \mathrm{m}, m-\mathrm{ArH}) ; \delta_{\mathrm{C}}(100 \mathrm{MHz}) 41.59(-)\left(-\mathrm{CH}_{2}-\right)$, $116.78(-)\left(=\mathrm{CH}_{2}\right), 128.38(+)(\mathrm{ArC}), 130.92(+)(\mathrm{ArC}), 133.09$ (+) (ArC), 133.17 (abs) (n-ArC), $134.28(+)(-\mathrm{CH}=), 162.13$ (abs) $\left(\mathrm{C}=\mathrm{O}\right.$, amide), $187.90(\mathrm{abs})(\mathrm{C}=\mathrm{O}) ; v_{\max } / \mathrm{cm}^{-1} 3261(\mathrm{NH})$ 1633 and $1652(2 \times \mathrm{C}=\mathrm{O}) ; \mathrm{m} / \mathrm{z} 189\left(\mathrm{M}^{+}\right), 105,77$.

\section{$N$-Allyl- $N$-methyl-2-oxopropanamide 10c}

A suspension of $N$-methylallyl amine $(0.40 \mathrm{~g}, 5.63 \mathrm{mmol})$, sodium hydrogen carbonate $(0.47 \mathrm{~g}, 5.60 \mathrm{mmol})$ and $\mathrm{CH}_{2} \mathrm{Cl}_{2}$ ( $5 \mathrm{~cm}^{3}$ anhydrous) was stirred at $0{ }^{\circ} \mathrm{C}$. To the cooled suspension 2-oxopropanoyl chloride 9a (0.5 g, $4.69 \mathrm{mmol})$ was added dropwise and the mixture was stirred at $\mathrm{rt}$ for $1 \mathrm{~h}$. The mixture was washed with water $\left(2 \times 5 \mathrm{~cm}^{3}\right)$, the organic layer was collected and dried (anhydrous $\mathrm{Na}_{2} \mathrm{SO}_{4}$ ), filtered and concentrated to afford 10c, a mobile yellow oil (mixed rotamers, $1: 1.4$ ) which was not purified further $(0.32 \mathrm{~g}, 50 \%) ; \delta_{\mathrm{H}}(400 \mathrm{MHz}) 2.34,2.36$ (3H, s, Me), 2.88, 2.89 (3H, s, N-Me), 3.83, 3.93 (2H, d, J 5.9, $\left.-\mathrm{CH}_{2}-\right), 5.15\left(2 \mathrm{H}, \mathrm{m},=\mathrm{CH}_{2}\right), 5.71\left(1 \mathrm{H}, \mathrm{m}, \mathrm{CH}=\mathrm{CH}_{2}\right)$.

\section{$\mathrm{N}$-Allyl- $\mathrm{N}$-methyl-2-oxo-2-phenylacetamide 10d}

$N$-Methyl allyl amine $(3.06 \mathrm{~g}, 0.043 \mathrm{~mol})$ and $\mathrm{NaHCO}_{3}(3.63 \mathrm{~g}$, $0.043 \mathrm{~mol}$ ) were stirred in $\mathrm{CH}_{2} \mathrm{Cl}_{2}$ anhydrous $\left(33 \mathrm{~cm}^{3}\right)$ at $0{ }^{\circ} \mathrm{C}$. 
To the cooled suspension 2-oxo-2-phenylacetyl chloride (6.05 g, $0.036 \mathrm{~mol}$ ) was added drop-wise and the mixture stirred at $\mathrm{rt}$ for $1 \mathrm{~h}$. The mixture was washed with water $\left(2 \times 30 \mathrm{~cm}^{3}\right)$, the organic layer was collected, dried (anhydrous $\mathrm{Na}_{2} \mathrm{SO}_{4}$ ), filtered and concentrated to afford 10d as a colourless, mobile oil (4.58 g, 63\%) [mixed rotamers, $1: 1.1$ ], which was not purified further. $R_{\mathrm{f}} 0.265 \mathrm{Et}_{2} \mathrm{O}$-petroleum spirit; $1: 1$ (Found: C, 70.70; H, 6.40; $\mathrm{N}, 6.79 . \mathrm{C}_{12} \mathrm{H}_{13} \mathrm{NO}_{2}$ requires: $\mathrm{C}, 70.92 ; \mathrm{H}, 6.45 ; \mathrm{N}, 6.89 \%$ ); $\delta_{\mathrm{H}}(400 \mathrm{MHz}) 2.85,3.02(3 \mathrm{H}, \mathrm{s}, \mathrm{Me}), 3.76,4.12(2 \mathrm{H}, \mathrm{d}, J 5.9$, $\left.-\mathrm{CH}_{2}-\right), 5.16,5.27\left(2 \mathrm{H}, 2 \times \mathrm{m},=\mathrm{CH}_{2}\right), 5.67,5.81(1 \mathrm{H}, \mathrm{m}, \mathrm{CH}=)$, $7.48(2 \mathrm{H}, \mathrm{m}, 2 \times o-\mathrm{ArH}), 7.58(1 \mathrm{H}, \mathrm{m}, p-\mathrm{ArH}), 7.90(2 \mathrm{H}, \mathrm{m}$, $2 \times m-\mathrm{ArH}) ; \delta_{\mathrm{C}}(100 \mathrm{MHz}) 31.27,34.29(\mathrm{~N}-\mathrm{Me}), 48.60,52.12$ $\left(-\mathrm{CH}_{2}-\right), 118.52,119.16\left(=\mathrm{CH}_{2}\right), 128.88,129.52\left(\mathrm{CH}=\mathrm{CH}_{2}\right)$, 131.26 (ArC), 131.64 (ArC), 132.88 (n-ArC), 134.62 (ArC), 166.63, 167.01 (amide $\mathrm{C}=\mathrm{O}), 191.34$ (ester $\mathrm{C}=\mathrm{O}$ ).

\section{$\mathrm{N}$-Allyl-2-(hydroxyimino)propanamide 8a}

$\alpha$-Keto amide 10a (4.0 g, $0.032 \mathrm{~mol})$, pyridine (3.76 g, $0.048 \mathrm{~mol})$ and $\mathrm{NH}_{2} \mathrm{OH} \cdot \mathrm{HCl}(3.31 \mathrm{~g}, 0.048 \mathrm{~mol})$ were stirred in $\mathrm{EtOH}\left(362 \mathrm{~cm}^{3}\right)$ at $\mathrm{rt}$ for $15 \mathrm{~h}$. The mixture was concentrated, taken up in $\mathrm{CHCl}_{3}\left(300 \mathrm{~cm}^{3}\right)$ and washed with water $(3 \times 100$ $\mathrm{cm}^{3}$ ). The organic layer was collected, dried, filtered and concentrated to afford the crude product $(3.74 \mathrm{~g}, 84 \%)$ which was purified by crystallisation; E-8a, colourless cubic crystals, mp 87-89.5 ${ }^{\circ} \mathrm{C}$ (from $\mathrm{C}_{6} \mathrm{H}_{6}$-petroleum spirit, $3.19 \mathrm{~g}, 71 \%$ ) (Found: C, 50.55; H, 6.86; N, 19.72. $\mathrm{C}_{6} \mathrm{H}_{10} \mathrm{~N}_{2} \mathrm{O}_{2}$ requires: $\mathrm{C}, 50.70 ; \mathrm{H}$, 7.04; N, 19.70\%); $\delta_{\mathrm{H}}(400 \mathrm{MHz}) 2.06\left(3 \mathrm{H}, \mathrm{s}, \mathrm{CH}_{3}\right), 3.94(2 \mathrm{H}$, $\left.\mathrm{m},-\mathrm{CH}_{2}-\right), 5.18\left(2 \mathrm{H}, \mathrm{m},=\mathrm{CH}_{2}\right), 5.82\left(1 \mathrm{H}, \mathrm{m}, \mathrm{CH}=\mathrm{CH}_{2}\right), 6.97$ $\left(1 \mathrm{H}\right.$, br s, N-H), $9.57\left(1 \mathrm{H}\right.$, br s, OH). Addition of $\mathrm{D}_{2} \mathrm{O}$ causes $\sim 50 \%$ reduction in signal intensity of both broad peaks); $\delta_{\mathrm{C}}(100 \mathrm{MHz}) 9.19\left(\mathrm{CH}_{3}\right), 41.76\left(-\mathrm{CH}_{2}-\right), 116.61\left(=\mathrm{CH}_{2}\right)$, $133.56(=\mathrm{CH}), 151.52(\mathrm{C}=\mathrm{N}), 164.00(\mathrm{C}=\mathrm{O}) ; v_{\max } / \mathrm{cm}^{-1} 3376$ (sharp, NH), 3178 (small broad, $\mathrm{OH}), 1663(\mathrm{C}=\mathrm{O}), 1630(\mathrm{C}=\mathrm{N})$; $m / z 142\left(\mathrm{M}^{+}\right), 143\left(\mathrm{M}^{+}+1\right), 125,56$.

\section{$\mathrm{N}$-Allyl-2-(hydroxyimino)-2-phenylacetamide 8b}

$\alpha$-Keto amide $10 b$ (5.13 g, $27 \mathrm{mmol}$ ), pyridine (3.22 g, $41 \mathrm{mmol}$ ) and $\mathrm{NH}_{2} \mathrm{OH} \cdot \mathrm{HCl}(2.83 \mathrm{~g}, 41 \mathrm{mmol})$ were stirred in $\mathrm{EtOH}(282$ $\mathrm{cm}^{3}$ ) for $15 \mathrm{~h}$ at $\mathrm{rt}$. The mixture was concentrated, taken up in $\mathrm{CHCl}_{3}\left(300 \mathrm{~cm}^{3}\right)$ and washed with water $\left(3 \times 200 \mathrm{~cm}^{3}\right)$. The organic layer was collected, dried (anhydrous $\mathrm{Na}_{2} \mathrm{SO}_{4}$ ), filtered and concentrated to afford the crude products, $(E)-\mathbf{8 b}$ and $(Z)-8 b$ in a $1: 2$ ratio $(4.13 \mathrm{~g}, 75 \%)$. The oximes, inseparable by column chromatography, were purified by crystallisation. $(E)$ $\mathbf{8 b}$ and $(Z)-8 \mathbf{b}$, colourless plates $(60 \%), \mathrm{mp} 127-128^{\circ} \mathrm{C}$ (from $\mathrm{C}_{6} \mathrm{H}_{6}$-petroleum spirit) (Found: C, 64.28; H, 5.80; N, 13.23. $\mathrm{C}_{11} \mathrm{H}_{12} \mathrm{~N}_{2} \mathrm{O}_{2}$ requires: $\left.\mathrm{C}, 64.71 ; \mathrm{H}, 5.88, \mathrm{~N}, 13.73 \%\right) ;(E)-8 \mathbf{b}$ $\delta_{\mathrm{H}}(400 \mathrm{MHz}) 3.96\left(2 \mathrm{H}, \mathrm{m},=\mathrm{CH}_{2}\right), 5.26\left(2 \mathrm{H}, \mathrm{m}, \mathrm{N}-\mathrm{CH}_{2}\right), 5.86$ $\left(1 \mathrm{H}, \mathrm{m}, \mathrm{CH}=\mathrm{CH}_{2}\right), 6.91(1 \mathrm{H}$, br m, N-H) $7.37(3 \mathrm{H}, \mathrm{m}, o-$, $p$-ArH), 7.55 (2H, m, m-ArH), $9.24(1 \mathrm{H}$, br s, OH); $(Z)-8 \mathbf{b}$ $\delta_{\mathrm{H}}(400 \mathrm{MHz}) 4.03\left(2 \mathrm{H}, \mathrm{m},=\mathrm{CH}_{2}\right), 5.16\left(2 \mathrm{H}, \mathrm{m}, \mathrm{N}-\mathrm{CH}_{2}\right), 5.86$ $\left(1 \mathrm{H}, \mathrm{m}, \mathrm{CH}-\mathrm{CH}_{2}\right), 6.35(1 \mathrm{H}$, br m, N-H $), 7.37(3 \mathrm{H}, \mathrm{m}, o-$ and $p$-ArH), 7.55 (2H, m, $m$-ArH), $10.48(1 \mathrm{H}, \mathrm{br} \mathrm{s}, \mathrm{OH}) ; \delta_{\mathrm{C}}(E)-$, (Z)-8b (100 MHz) 41.72, $41.93(-)\left(\mathrm{N}-\mathrm{CH}_{2}\right), 116.66,117.17(-)$ $\left(=\mathrm{CH}_{2}\right), 126.21,127.23,127.78,128.84,129.52,130.16,132.92$, $133.73(+)(10 \times \mathrm{ArC}), 128.67$ (abs.) ((E)-oxime; n-ArC), 131.56 (abs.) ((Z)-oxime; $n$-ArC) $132.92,133.73(+)(C \mathrm{H}=$ $\left.\mathrm{CH}_{2}\right), 151.18,152.19$ (abs.) $(\mathrm{C}=\mathrm{N}), 163.15,163.36$ (abs.) $(\mathrm{C}=\mathrm{O})$; $\mathrm{m} / \mathrm{z} 204\left(\mathrm{M}^{+}\right), 187,119,104,77,56, v_{\max } / \mathrm{cm}^{-1} 3321$ and 3163 $(\mathrm{NH}$ and $\mathrm{OH}), 1634$ and $1606((E)$ - and $(Z)$-isomers $\mathrm{C}=\mathrm{O})$.

\section{$N$-Allyl-2-(hydroxyimino)- $N$-methylpropanamide 8c}

$\alpha$-Keto amide 10c (2 g, $14.2 \mathrm{mmol})$, pyridine (1.68 g, 21.3 $\mathrm{mmol})$ and $\mathrm{NH}_{2} \mathrm{OH} . \mathrm{HCl}(1.48 \mathrm{~g}, 21.3 \mathrm{mmol})$ were stirred in EtOH $\left(230 \mathrm{~cm}^{3}\right)$ at $\mathrm{rt}$ for $15 \mathrm{~h}$. The mixture was concentrated, taken up in $\mathrm{CH}_{2} \mathrm{Cl}_{2}\left(200 \mathrm{~cm}^{3}\right)$ and washed with water $(2 \times$ $100 \mathrm{~cm}^{3}$ ). The organic layer was collected, dried (anhydrous $\mathrm{Na}_{2} \mathrm{SO}_{4}$ ), filtered and concentrated. The crude mixture was purified by flash chromatography $\left(\mathrm{Et}_{2} \mathrm{O}\right.$-petroleum spirit; $\left.1: 1\right)$ yielding $(E)-8 \mathrm{c}(0.43 \mathrm{~g}, 20 \%)$ and $(Z)-8 \mathrm{c}(0.56 \mathrm{~g}, 25 \%)$ each as a pair of rotamers; $(E)-8 \mathrm{c}$ (rotamer ratio $1: 1.2$ ), a colourless mobile oil, solidifying in the cold, $\mathrm{mp} 90-92{ }^{\circ} \mathrm{C}$ (Found: $\mathrm{C}$, 54.10; H, 7.65; N, 17.84. $\mathrm{C}_{7} \mathrm{H}_{12} \mathrm{~N}_{2} \mathrm{O}_{2}$ requires: $\mathrm{C}, 53.85 ; \mathrm{H}, 7.69$; $\mathrm{N}, 17.95) ; \delta_{\mathrm{H}}(400 \mathrm{MHz}) 2.06,2.08(3 \mathrm{H}, \mathrm{s}, \mathrm{Me}), 2.96,3.01(3 \mathrm{H}$, $\mathrm{s}, \mathrm{N}-\mathrm{Me}), 4.03\left(2 \mathrm{H}, \mathrm{t}, J 7.3,=\mathrm{CH}_{2}\right), 5.21\left(2 \mathrm{H}, \mathrm{d}, J 10.3,-\mathrm{CH}_{2}\right)$, $5.78\left(1 \mathrm{H}, \mathrm{m}, \mathrm{CH}=\mathrm{CH}_{2}\right), 9.47,9.55(1 \mathrm{H}, \mathrm{s}, \mathrm{OH}) ; \delta_{\mathrm{C}}(100 \mathrm{MHz})$ $12.08,12.25\left(\mathrm{CH}_{3}\right), 32.93,36.03\left(\mathrm{~N}-\mathrm{CH}_{3}\right), 50.00,53.48\left(-\mathrm{CH}_{2}-\right)$, $117.93\left(=\mathrm{CH}_{2}\right), 131.86,133.09\left(-\mathrm{CH}=\mathrm{CH}_{2}\right), 151.98,152.07$ $(\mathrm{C}=\mathrm{N}), 166.67,167.23(\mathrm{C}=\mathrm{O}) ;(Z)-8 \mathrm{c}$ (rotamer ratio 1 : 1.1), a colourless mobile oil which solidified on standing in the cold, mp 91-93 ${ }^{\circ} \mathrm{C}$ (Found: C, 53.23; H, 7.83; N, 18.02. $\mathrm{C}_{7} \mathrm{H}_{12} \mathrm{~N}_{2} \mathrm{O}_{2}$ requires: $\mathrm{C}, 53.85 ; \mathrm{H}, 7.69 ; \mathrm{N}, 17.95) ; \delta_{\mathrm{H}}(400 \mathrm{MHz}) 2.01,2.04$ $\left(3 \mathrm{H}, \mathrm{s}, \mathrm{CH}_{3}\right), 2.88,2.91\left(3 \mathrm{H}, \mathrm{s}, \mathrm{N}-\mathrm{CH}_{3}\right), 3.81,4.02(2 \mathrm{H}, \mathrm{d}, J 5.9$, $-\mathrm{CH}_{2}-$ and $\left.J 5.4,-\mathrm{CH}_{2}-\right), 5.20\left(2 \mathrm{H}, \mathrm{m},=\mathrm{CH}_{2}\right), 5.75(1 \mathrm{H}, \mathrm{m}$, $\left.\mathrm{CH}=\mathrm{CH}_{2}\right), 9.35(1 \mathrm{H}$, br s, $\mathrm{NOH}) ; \delta_{\mathrm{C}}(100 \mathrm{MHz}) 16.88,17.26$ $(+)\left(\mathrm{CH}_{3}\right), 31.31,34.16(+)\left(\mathrm{N}-\mathrm{CH}_{3}\right), 48.51,52.37(-)\left(-\mathrm{CH}_{2}-\right)$, $117.68,118.27(-)\left(=\mathrm{CH}_{2}\right), 131.60,132.79(+)\left(\mathrm{CH}=\mathrm{CH}_{2}\right)$, 151.52 (abs.) $(\mathrm{C}=\mathrm{N}), 166.25,166.46$ (abs.) $(\mathrm{C}=\mathrm{O})$.

\section{$\mathrm{N}$-Allyl-2-(hydroxyimino)- $N$-methyl-2-phenylacetamide 8d}

$\alpha$-Keto amide 10d (2 g, $14.9 \mathrm{mmol})$, pyridine (1.17 g, 14.9 mmol) and $\mathrm{NH}_{2} \mathrm{OH} \cdot \mathrm{HCl}(1.03 \mathrm{~g}, 14.9 \mathrm{mmol})$ were stirred in $\mathrm{EtOH}\left(200 \mathrm{~cm}^{3}\right)$ at reflux temperature for $15 \mathrm{~h}$. The mixture was allowed to cool to $\mathrm{rt}$ was concentrated, taken up in $\mathrm{CH}_{2} \mathrm{Cl}_{2}(200$ $\left.\mathrm{cm}^{3}\right)$ and washed with water $\left(2 \times 100 \mathrm{~cm}^{3}\right)$. The organic layer was collected, dried (anhydrous $\mathrm{Na}_{2} \mathrm{SO}_{4}$ ), filtered and concentrated affording the crude product which was purified by flash chromatography $\left(\mathrm{Et}_{2} \mathrm{O}\right.$-petroleum spirit, $\left.1: 4\right)$ to afford $(Z)-8 d$ as a pair of rotamers $(1.24 \mathrm{~g}, 58 \%)$; $(Z)-8 d$ (rotamer ratio 1 : 1.2), fine colourless needles, mp $104-106{ }^{\circ} \mathrm{C}$, (from $\mathrm{C}_{6} \mathrm{H}_{6}-$ petroleum spirit) (Found: $\mathrm{C}, 65.82 ; \mathrm{H}, 5.96 ; \mathrm{N}, 13.20$. $\mathrm{C}_{12} \mathrm{H}_{14} \mathrm{~N}_{2} \mathrm{O}_{2}$ requires: $\left.\mathrm{C}, 66.04 ; \mathrm{H}, 6.47 ; \mathrm{N}, 12.84 \%\right) ; \delta_{\mathrm{H}}(400$ MHz) 2.86, 3.05 (3H, s, N-Me), 3.78, 4.18 (2H, d, J 6.3, $-\mathrm{CH}_{2-}$ and $\left.J 5.4,-\mathrm{CH}_{2}-\right), 5.14,5.26\left(2 \mathrm{H}, \mathrm{m},=\mathrm{CH}_{2}\right), 5.62,5.82(1 \mathrm{H}, \mathrm{m}$, $\left.\mathrm{CH}=\mathrm{CH}_{2}\right), 7.36(3 \mathrm{H}, \mathrm{m}, o-$ and $p-\mathrm{ArH}), 7.59(2 \mathrm{H}, \mathrm{m}, 2 \times$ $m-\mathrm{ArH}) ; \delta_{\mathrm{C}}(100 \mathrm{MHz}) 31.10$ and $34.33(+)(\mathrm{N}-\mathrm{Me}), 48.72$ and $52.93(-)\left(-\mathrm{CH}_{2}-\right), 118.02$ and $119.12(-)\left(=\mathrm{CH}_{2}\right), 126.25(+)$ $(\mathrm{ArC}), 128.71 \quad(+) \quad(\mathrm{ArC}), 130.16 \quad(+) \quad(\mathrm{ArC}), 130.88$ (abs.) (n-ArC), 131.77 and $132.58(+)\left(C \mathrm{H}=\mathrm{CH}_{2}\right), 153.47$ (abs.) $(\mathrm{C}=\mathrm{N}), 164.93$ (abs.) $(\mathrm{C}=\mathrm{O})$.

\section{2,6-Dimethyl-5-oxo-2,3,4,5-tetrahydropyrazin-1-ium-1-olate 1a}

A solution of the oxime $(E)-8 \mathrm{a}(0.5 \mathrm{~g}, 3.52 \mathrm{mmol})$ in xylene $\left(125 \mathrm{~cm}^{3}\right)$, was heated at reflux in the presence of hydroquinone $(1 \% \mathrm{w} / \mathrm{v} ; 1.25 \mathrm{~g})$ under a nitrogen atmosphere for $24 \mathrm{~h}$. The mixture was allowed to cool to $\mathrm{rt}$ and the solvent removed under reduced pressure. The residue was taken up in $\mathrm{CHCl}_{3}$ $\left(10 \mathrm{~cm}^{3}\right)$ and the hydroquinone which precipitated, was removed (in vacuo). The filtrate was concentrated yielding the crude product which was purified by flash column chromatography $\left(\mathrm{Et}_{2} \mathrm{O}-\mathrm{MeOH} ; 20: 1\right)$ to afford nitrone $(0.324 \mathrm{~g}, 65 \%)$ and returned oxime $(0.143 \mathrm{~g}, 29 \%)$; 1a, pale yellow cubic crystals $\mathrm{mp} 144-146^{\circ} \mathrm{C}$ (from $\mathrm{Et}_{2} \mathrm{O}$ ) (Found: C, 50.82; H, 7.18; N, 19.37 . $\mathrm{C}_{6} \mathrm{H}_{10} \mathrm{~N}_{2} \mathrm{O}_{2}$ requires: $\left.\mathrm{C}, 50.70 ; \mathrm{H}, 7.04 ; \mathrm{N}, 19.72 \%\right) ; \delta_{\mathrm{H}}(400$ MHz) $1.55(3 \mathrm{H}, \mathrm{d}, J 6.6,2-\mathrm{Me}), 2.18(3 \mathrm{H}, \mathrm{s}, 6-\mathrm{Me}), 3.32(1 \mathrm{H}$, ddd, $J 13.4,4.5,4.5,3 \mathrm{~b}-\mathrm{H}), 3.78$ (1H, ddd, $J 13.4,4.7,2.3$, $3 \mathrm{a}-\mathrm{H}), 4.12(1 \mathrm{H}, \mathrm{m}, 2-\mathrm{H}), 7.46(1 \mathrm{H}, \mathrm{br} \mathrm{s}, \mathrm{NH}) ; \delta_{\mathrm{C}}(100 \mathrm{MHz})$ $11.15(+)(2-\mathrm{Me}), 15.94(+)(6-\mathrm{Me}), 42.57(-)(3-\mathrm{C}), 63.96(+)$ (2-C), 138.44 (abs.) $(C=\mathrm{N}), 161.62$ (abs.) $(C=\mathrm{O}) ; v_{\max } / \mathrm{cm}^{-1} 3190$ $(\mathrm{N}-\mathrm{H}), 1672(\mathrm{C}=\mathrm{O}), 1462(\mathrm{C}=\mathrm{N}) ; m / z 142\left(\mathrm{M}^{+}\right)$. Addition of $\mathrm{D}_{2} \mathrm{O}$ causes $\sim 50 \%$ reduction in signal intensity of the signal representing the $\mathrm{NH}$ proton.

\section{2-Methyl-5-oxo-6-phenyl-2,3,4,5-tetrahydropyrazin-1-ium-1- olate $1 b$}

A solution of $(E)$ - and $(Z)-8 \mathbf{b}$ (ratio $2: 1)(0.20 \mathrm{~g}, 1.06 \mathrm{mmol})$ in xylene $\left(68 \mathrm{~cm}^{3}\right)$ was heated at reflux in the presence of hydro- 
quinone $(1 \% \mathrm{w} / \mathrm{v} ; 0.68 \mathrm{~g})$ under a nitrogen atmosphere for $19 \mathrm{~h}$. The mixture was allowed to cool to $\mathrm{rt}$ and the solvent removed under reduced pressure. The residue was taken up in $\mathrm{CHCl}_{3}$ $\left(5 \mathrm{~cm}^{3}\right)$ and the hydroquinone which precipitated was removed (in vacuo). The filtrate was concentrated yielding the crude product which was purified by column chromatography $\left(\mathrm{Et}_{2} \mathrm{O}\right.$ $\mathrm{MeOH} ; 20: 1)$ to afford nitrone $(125 \mathrm{mg}, 63 \%) ; \mathbf{1 b}$, colourless cubic crystals, mp $196-198{ }^{\circ} \mathrm{C}$ (from $\mathrm{CHCl}_{3}$-petroleum spirit). (Found: $\mathrm{C}, 64.49 ; \mathrm{H}, 5.69 ; \mathrm{N}, 13.55 . \mathrm{C}_{11} \mathrm{H}_{12} \mathrm{~N}_{2} \mathrm{O}_{2}$ requires: $\mathrm{C}$, $64.71 ; \mathrm{H}, 5.88 ; \mathrm{N}, 13.73 \%) ; \delta_{\mathrm{H}}(400 \mathrm{MHz}) 1.64(3 \mathrm{H}, \mathrm{d}, J 7.0$, 2-Me), 3.34 (1H, ddd, $J$ 13.5, 4.6, 4.6, 3b-H), 3.85 (1H, ddd, $J$ 13.5, 4.5, 2.2, 3a-H), $4.24(1 \mathrm{H}, \mathrm{m}, 2-\mathrm{H}), 7.41(3 \mathrm{H}, \mathrm{m}, o-$, p-ArH), $7.60\left(1 \mathrm{H}\right.$, br s, N-H), $7.66(2 \mathrm{H}, \mathrm{m}, m-\mathrm{ArH}) ; \delta_{\mathrm{C}}(100$ MHz) 16.07 (+) (2-Me), 42.23 (-) (3-C), 65.79 (+) (2-C), $127.74(+)$ (ArC), 128.04 (abs.) (n-ArC), $129.65(+)(\mathrm{ArC})$, 130.29 (+) (ArC), 137.25 (abs.) (6-C), 161.58 (abs.) (5-C); $\mathrm{m} / \mathrm{z} 204\left(\mathrm{M}^{+}\right), 150,120,105,91,77 ; v_{\max } / \mathrm{cm}^{-1} 3182(\mathrm{~N}-\mathrm{H}), 1673$ $(\mathrm{C}=\mathrm{O}), 1463(\mathrm{C}=\mathrm{N})$.

\section{2,4,6-Trimethyl-5-oxo-2,3,4,5-tetrahydropyrazin-1-ium-1-olate $1 \mathrm{c}$}

$(E)-8 \mathrm{c}(0.23 \mathrm{~g}, 1.47 \mathrm{mmol})$ was stirred at reflux in xylene $\left(40 \mathrm{~cm}^{3}\right)$ under a nitrogen atmosphere in the presence of hydroquinone $(1 \% \mathrm{w} / \mathrm{v}, 0.40 \mathrm{~g})$ for $20 \mathrm{~h}$. The mixture was allowed to cool to $\mathrm{rt}$ and was filtered (in vacuo) to remove hydroquinone. The filtrate was concentrated under reduced pressure and further hydroquinone was precipitated by addition of $\mathrm{CHCl}_{3}$ $\left(5 \mathrm{~cm}^{3}\right)$, filtration and concentration afforded the crude product. Purification by flash column chromatography $\left(\mathrm{Et}_{2} \mathrm{O}\right.$ petroleum spirit, $3: 1)$ yielded nitrone $(204 \mathrm{mg}, 88 \%)$; $1 \mathbf{c}$, off white cubic crystals, $\mathrm{mp} 91-93{ }^{\circ} \mathrm{C}$ (from $\mathrm{C}_{6} \mathrm{H}_{6}$-petroleum spirit) (Found: C, 53.92; H, 7.88; N, 17.71. $\mathrm{C}_{7} \mathrm{H}_{12} \mathrm{~N}_{2} \mathrm{O}_{2}$ requires: $\mathrm{C}$, $53.83 ; \mathrm{H}, 7.74 ; \mathrm{N}, 17.94 \%) ; \delta_{\mathrm{H}}(400 \mathrm{MHz}) 1.53(3 \mathrm{H}, \mathrm{d}, J 6.8$, 2-Me), 2.21 (3H, s, 6-Me), $3.08\left(3 \mathrm{H}, \mathrm{s}, \mathrm{N}-\mathrm{CH}_{3}\right), 3.24(1 \mathrm{H}, \mathrm{dd}$, $J 13.2,5.4,3 \mathrm{~b}-\mathrm{H}), 3.77(1 \mathrm{H}, \mathrm{dd}, J 13.2,4.9,3 \mathrm{a}-\mathrm{H}), 4.11(1 \mathrm{H}, \mathrm{m}$, $2-\mathrm{H}) ; \delta_{\mathrm{C}}(100 \mathrm{MHz}) 11.72(2-\mathrm{Me}), 16.18(6-\mathrm{Me}), 34.69(\mathrm{~N}-\mathrm{Me})$, 50.23 (3-C), 63.18 (2-C), 138.59 (6-C), 159.52 (5-C); m/z 157 $\left(\mathrm{M}^{+}+1\right)$.

\section{5,6a-Dimethylhexahydro-6H-pyrrolo[3,4-c] isoxazol-6-one 11b}

Oxime $(Z)-8 c(0.20 \mathrm{~g}, 1.28 \mathrm{mmol})$ was heated at reflux in xylene $\left(40 \mathrm{~cm}^{3}\right)$ under a nitrogen atmosphere in the presence of hydroquinone $(1 \% \mathrm{w} / \mathrm{v}, 0.4 \mathrm{~g})$ for $20 \mathrm{~h}$. The reaction was allowed to cool to $\mathrm{rt}$ and was concentrated under reduced pressure. Hydroquinone was precipitated by addition of $\mathrm{CHCl}_{3}\left(10 \mathrm{~cm}^{3}\right)$ and removed by filtration (in vacuo). Concentration of the filtrate afforded the crude product. Purification by flash chromatography $\left(\mathrm{Et}_{2} \mathrm{O}\right)$ yielded $\mathbf{1 1 b}(0.12 \mathrm{~g}, 60 \%)$ as colourless needles (mp 108-109.5 ${ }^{\circ} \mathrm{C}, \mathrm{C}_{6} \mathrm{H}_{6}$-hexane) (Found: $\mathrm{C}, 53.36 ; \mathrm{H}, 8.06$; $\mathrm{N}, 17.33 . \mathrm{C}_{7} \mathrm{H}_{12} \mathrm{~N}_{2} \mathrm{O}_{2}$ requires $\left.\mathrm{C}, 53.85 ; \mathrm{H}, 7.69 ; \mathrm{N}, 17.95 \%\right)$; $\delta_{\mathrm{H}}(400 \mathrm{MHz}) 1.45(3 \mathrm{H}, \mathrm{s}, 6 \mathrm{a}-\mathrm{Me}), 2.81(1 \mathrm{H}, \mathrm{m}, 3 \mathrm{a}-\mathrm{H}), 2.85$ $(3 \mathrm{H}, \mathrm{s}, \mathrm{N}-\mathrm{Me}), 3.15\left(1 \mathrm{H}, \mathrm{dd}, J 10.3,2.6,4^{\prime}-\mathrm{H}\right), 3.60(1 \mathrm{H}, \mathrm{dd}$, $J$ 10.3, 8.4, 4-H), 3.93 (2H, br m, 3-H, $\left.3^{\prime}-\mathrm{H}\right), 5.00$ (br s, NH); $\delta_{\mathrm{H}}(400 \mathrm{MHz})\left(-40^{\circ} \mathrm{C}\right) 1.53(3 \mathrm{H}, \mathrm{s}, 3 \mathrm{a}-\mathrm{Me}), 2.92\left(4 \mathrm{H}, \mathrm{N}-\mathrm{CH}_{3}\right.$, $3 \mathrm{a}-\mathrm{H}), 3.27\left(1 \mathrm{H}, \mathrm{dd}, J 10.5,2.7,4^{\prime}-\mathrm{H}\right), 3.70(1 \mathrm{H}$, br t, $4-\mathrm{H}), 3.92$ $\left(1 \mathrm{H}\right.$, br t, 3-H), $4.17\left(1 \mathrm{H}\right.$, br dd, $\left.3^{\prime}-\mathrm{H}\right), 5.06(1 \mathrm{H}$, br s, $\mathrm{N}-\mathrm{H}) ; \delta_{\mathrm{C}}$ $(100 \mathrm{MHz}) 18.49(+)(6 \mathrm{a}-\mathrm{Me}), 30.08(+)(\mathrm{N}-\mathrm{Me}), 45.33(+)$ (3a-C), 52.46 (-) (4-C), 70.55 (abs.) (6a-C), 78.83 (-) (3-C), 173.64 (abs.) (6-C), $\mathrm{M}^{*+}$ 156. NOEDS results for $\mathbf{1 1 b}$ : irradiation of $4-\mathrm{H}$ caused the following enhancements $4^{\prime}-\mathrm{H}(20 \%)$, $3 \mathrm{a}-\mathrm{H}(13 \%)$ and $6 \mathrm{a}-\mathrm{Me}(3 \%)$.

\section{5-Methyl-6a-phenylhexahydro-6H-pyrrolo[3,4-c]isoxazol-6-one} $11 \mathrm{c}$

Oxime $(Z)-8 d(0.177 \mathrm{~g}, 0.811 \mathrm{mmol})$ was heated at reflux in xylene $\left(20 \mathrm{~cm}^{3}\right)$ in the presence of hydroquinone $(1 \% \mathrm{w} / \mathrm{v}$, $0.20 \mathrm{~g}$ ) under a nitrogen atmosphere for $24 \mathrm{~h}$. The mixture was allowed to cool to $\mathrm{rt}$ and precipitated hydroquinone removed by filtration (in vacuo). The filtrate was concentrated and further hydroquinone precipitated by the addition of $\mathrm{CHCl}_{3}\left(5 \mathrm{~cm}^{3}\right)$. Filtration and concentration afforded the crude product, which was purified by flash chromatography $\left(\mathrm{Et}_{2} \mathrm{O}\right)$ to afford 11c (160 $\mathrm{mg}, 91 \%)$ as brown cubic crystals, $\mathrm{mp} 149-150{ }^{\circ} \mathrm{C}\left(\mathrm{C}_{6} \mathrm{H}_{6}-\right.$ petroleum spirit) (Found: $\mathrm{C}, 66.08 ; \mathrm{H}, 6.48 ; \mathrm{N}, 12.50 . \mathrm{C}_{12} \mathrm{H}_{14^{-}}$ $\mathrm{N}_{2} \mathrm{O}_{5}$ requires: $\left.\mathrm{C}, 66.04 ; \mathrm{H}, 6.47 ; \mathrm{N}, 12.84 \%\right) ; \delta_{\mathrm{H}}(400 \mathrm{MHz})$ $2.95(3 \mathrm{H}, \mathrm{s}, \mathrm{N}-\mathrm{Me}), 3.32\left(2 \mathrm{H}, \mathrm{d}, J 9.3,3-\mathrm{H}, 3^{\prime}-\mathrm{H}\right), 3.79(1 \mathrm{H}, \mathrm{dd}$, $J$ 10.3, 7.8, 3a-H), 4.05 (1H, br m, 4'-H), 4.18 (1H, br m, 4-H), $5.82(1 \mathrm{H}$, br s, NH), $7.35(3 \mathrm{H}, \mathrm{m}, o-\& p-\mathrm{ArH}), 7.49(2 \mathrm{H}, \mathrm{d}$, $J$ 7.3, $m$-ArH); $\delta_{\mathrm{C}}(100 \mathrm{MHz}) 30.38(\mathrm{~N}-\mathrm{Me}), 46.56$ (br, 3a-C), 52.42 (4-C), 76.58 (6a-C), 78.87 (br, 3-C), 126.34 (ArC), 128.33 (ArC), 128.76 (ArC), 136.40 (n-ArC), $172.49(\mathrm{C}=\mathrm{O}) . X$-Ray crystal determination for 11c. The structure was solved by direct methods, SHELXS-97, ${ }^{19}$ and refined by full matrix least squares using SHELXL-9 ${ }^{20}$ SHELX operations were automated using ORTEX which was also used to obtain the drawings. ${ }^{18}$ Data were corrected for Lorentz and polarization effects but not for absorption. The hydrogen on N(1) was located and refined all other hydrogen atoms were included in calculated positions with thermal parameters $30 \%$ larger than the atom to which they were attached. The non-hydrogen atoms were refined anisotropically. All calculations were performed on a Pentium PC. Crystal data $\uparrow$ for 11c, see Table 2.

\section{3a,7-Dimethyl-2-(phenylsulfonyl)tetrahydro- $2 \mathrm{H}$-isoxazolo [2,3-a]pyrazin-4(5H)-one 13a}

A solution of 1a (0.05 g, $0.352 \mathrm{mmol})$ and phenyl vinyl sulfone $(0.071 \mathrm{~g}, 0.422 \mathrm{mmol})$ in toluene $\left(30 \mathrm{~cm}^{3}\right)$ under a nitrogen atmosphere, was heated at reflux for $48 \mathrm{~h}$. The reaction mixture was allowed to cool to $\mathrm{rt}$ and the solvent removed under reduced pressure. Purification by flash column chromatography $\left(\mathrm{Et}_{2} \mathrm{O}\right.$ with $\mathrm{MeOH} \%$ gradient) afforded 13a (65 mg, 59\%) and returned nitrone $(14.2 \mathrm{mg}, 28 \%)$; 13a, pale yellow crystals, $\mathrm{mp}$ $185-188^{\circ} \mathrm{C}$ (from $\mathrm{CHCl}_{3}$-hexane) (Found: $\mathrm{C}, 54.61 ; \mathrm{H}, 5.51 ; \mathrm{N}$, 8.57. $\mathrm{C}_{14} \mathrm{H}_{18} \mathrm{~N}_{2} \mathrm{O}_{4} \mathrm{~S}$ requires: $\left.\mathrm{C}, 54.19 ; \mathrm{H}, 5.81 ; \mathrm{N}, 9.03 \%\right)$; $\delta_{\mathrm{H}}(400 \mathrm{MHz}) 1.28(3 \mathrm{H}, \mathrm{d}, J 5.9,7-\mathrm{Me}), 1.47(3 \mathrm{H}, \mathrm{s}, 3 \mathrm{a}-\mathrm{Me})$, 2.76 (1H, dd, $J 13.6,7.7,3 \mathrm{a}-\mathrm{H}), 3.14$ (2H, m, 6b-H, 3b-H), 3.18 $(1 \mathrm{H}, \mathrm{ddd}, J 13.1,4.3,4.5,6 \mathrm{a}-\mathrm{H}), 3.48(1 \mathrm{H}, \mathrm{m}, 7-\mathrm{H}), 5.04(1 \mathrm{H}$, $\mathrm{dd}, J 7.7,7.7,2-\mathrm{H}), 7.12(1 \mathrm{H}, \mathrm{d}, J 4.5, \mathrm{NH}), 7.59(2 \mathrm{H}, \mathrm{m}, 2 \times$ $\mathrm{ArH}), 7.69(1 \mathrm{H}, \mathrm{m}, 1 \times \mathrm{ArH}), 7.93(2 \mathrm{H}, \mathrm{m}, 2 \times \mathrm{ArH}) ; \delta_{\mathrm{C}}(100$ $\mathrm{MHz}) 16.60(+)(7-\mathrm{Me}), 24.28(+)(3 \mathrm{a}-\mathrm{Me}), 39.35(-)$ (3-C), $45.04(-)$ (6-C), $55.28(+)(7-\mathrm{C}), 69.84$ (abs.) (3a-C), $93.32(+)$ (2-C), $128.86(+)$ (ArC), $129.49(+)(\mathrm{ArC}), 134.46(+)(\mathrm{ArC})$, 137.39 (abs.) (n-ArC), 171.70 (abs.) (4-C); $v_{\max } / \mathrm{cm}^{-1} 3180,1679$, 1461, 1369. NOEDS results for 13a: irradiation of 3a-H caused the following enhancements $3 \mathrm{a}-\mathrm{Me}(1.5 \%), 3 \mathrm{~b}-\mathrm{H}(25 \%) 7-\mathrm{H}$ $(-2.76 \%)$ and $2-\mathrm{H}(11 \%)$. Irradiation of $7-\mathrm{H}$ caused the following enhancements $7-\mathrm{Me}(3 \%), 3 \mathrm{a}-\mathrm{H}(-0.8 \%), 6 \mathrm{~b}-\mathrm{H}(3.5 \%)$. Irradiation of $2-\mathrm{H}$ caused enhancements on $3 \mathrm{a}-\mathrm{Me}(2 \%)$ and $3 \mathrm{a}-\mathrm{H}(5 \%)$.

\section{3a,5,7-Trimethyl-2-(phenylsulfonyl)tetrahydro-2 $\mathrm{H}$-isoxazolo- [2,3-a]pyrazin-4(5H)-one 13b}

A solution of nitrone $1 \mathrm{c}(0.05 \mathrm{~g}, 0.321 \mathrm{mmol})$ and phenyl vinyl sulfone $(0.065 \mathrm{~g}, 0.385 \mathrm{mmol})$ in toluene $\left(28 \mathrm{~cm}^{3}\right)$ under a nitrogen atmosphere was heated at reflux for $72 \mathrm{~h}$. The reaction mixture was allowed to cool to rt and the solvent was removed under reduced pressure. The crude mixture was purified by flash chromatography ( $\mathrm{Et}_{2} \mathrm{O}$-petroleum spirit $2: 1$ ) yielding $\mathbf{1 3 b}$ $(0.051 \mathrm{~g}, 49 \%)$ and a trace of nitrone; $\mathbf{1 3 b}$, a colourless, odourless viscous oil, $R_{\mathrm{f}} 0.083\left(\mathrm{Et}_{2} \mathrm{O}\right.$ ) (Found: C, 55.28; H, 6.15; N, 8.60. $\mathrm{C}_{15} \mathrm{H}_{20} \mathrm{~N}_{2} \mathrm{SO}_{4}$ requires: C, 55.56; $\mathrm{H}, 6.17 ; \mathrm{N}, 8.64 \%$ ); $\delta_{\mathrm{H}}(400 \mathrm{MHz}) 1.30(3 \mathrm{H}, \mathrm{d}, J 5.9,7-\mathrm{Me}), 1.47(3 \mathrm{H}, \mathrm{s}, 3 \mathrm{a}-\mathrm{Me})$, $2.79(1 \mathrm{H}, \mathrm{dd}, J 13.1,7.8,3 \mathrm{a}-\mathrm{H}), 2.97(3 \mathrm{H}, \mathrm{s}, \mathrm{N}-\mathrm{Me}), 3.09(2 \mathrm{H}$, $\mathrm{m}, 6 \mathrm{a} / 3 \mathrm{~b}-\mathrm{H}), 3.22(1 \mathrm{H}, \mathrm{dd}, J 12.2$ and $10.7,6 \mathrm{~b}-\mathrm{H}), 3.55(1 \mathrm{H}, \mathrm{m}$,

$†$ CCDC reference numbers 197234 and 197325. See http:// www.rsc.org/suppdata/ob/b2/b210943n/ for crystallographic data in .cif or other electronic format. 
Table 2 Crystal data and structure refinement for 11c

$\begin{array}{ll}\text { Identification code } & \text { jf9b } \\ \text { Empirical formula } & \mathrm{C}_{22} \mathrm{H}_{23} \mathrm{~N} \mathrm{O}_{5} \\ \text { Formula weight } & 381.41 \\ \text { Temperature } & 298(2) \mathrm{K} \\ \text { Wavelength } & 0.71069 \AA \\ \text { Crystal system } & \text { Monoclinic } \\ \text { Space group } & P 2 / n \\ \text { Unit cell dimensions } & a=15.243(6) \AA \\ & b=8.697(4) \AA \beta=108.21(4)^{\circ} \\ & c=15.245(10) \AA \\ \text { Volume } & 1919.8(17) \AA^{3} \\ Z & 4 \\ \text { Density (calculated) } & 1.320 \mathrm{Mg} \mathrm{m}^{-3} \\ \text { Absorption coefficient } & 0.094 \mathrm{~mm}^{-1} \\ F(000) & 808 \\ \text { Crystal size } & 0.29 \times 0.22 \times 0.19 \mathrm{~mm} \\ \text { Theta range for data collection } & 1.65 \text { to } 20.90^{\circ} . \\ \text { Index ranges } & -15<=h<=12 ;-8<=k<=8 ;-14<=l<=14 \\ \text { Reflections collected } & 3086 \\ \text { Independent reflections } & 1796[R(\text { int })=0.0646] \\ \text { Reflections observed }(>2 \sigma) & 1310 \\ \text { Data Completeness } & 0.881 \\ \text { Max and min transmission } & 0.9827 \text { and } 0.9734 \\ \text { Refinement method } & \text { Full-matrix least-squares on } F^{2} \\ \text { Data/restraints/parameters } & 1796 / 0 / 264 \\ \text { Goodness-of-fit on } F^{2} & 1.063 \\ \text { Final R indices }[I>2 \sigma(I)] & R_{1}=0.0648 \mathrm{w} R_{2}=0.1562 \\ R \text { indices (all data) } & R_{1}=0.0918 \mathrm{w} R_{2}=0.1726 \\ \text { Largest diff. peak and hole } & 0.168 \text { and }-0.183 \text { e } \AA^{-3} \\ & \end{array}$

$R$ indices; $R_{1}=\left[\Sigma|| F_{\mathrm{o}}|-| F_{\mathrm{c}}||\right] / \Sigma\left|F_{\mathrm{o}}\right|($ based on $F), \mathrm{w} R_{2}=\left[\left[\Sigma_{\mathrm{w}}\left(\left|F_{\mathrm{o}}{ }^{2}-F_{\mathrm{c}}{ }^{2}\right|\right)^{2}\right] /\left[\Sigma_{\mathrm{w}}\left(F_{\mathrm{o}}{ }^{2}\right)^{2}\right]\right]^{1 / 2}\left(\right.$ based on $\left.F^{2}\right) . w=1 /\left[\left(\sigma F_{\mathrm{o}}\right)^{2}+\left(0.0731^{*} \mathrm{P}\right)^{2}+1.78^{*} \mathrm{P}\right]$. Goodness-of-fit $=\left[\Sigma_{\mathrm{w}}\left(F_{\mathrm{o}}{ }^{2}-F_{\mathrm{c}}{ }^{2}\right)^{2} /(\text { Nobs }-N \text { parameters })\right]^{1 / 2}$.

7-H), $5.05(1 \mathrm{H}, \mathrm{dd}, J 8.3,8.3,2-\mathrm{H}), 7.60(2 \mathrm{H}, \mathrm{m}, 2 \times \mathrm{ArH}), 7.71$ $(1 \mathrm{H}, \mathrm{m}, 1 \times \mathrm{ArH}), 7.94(2 \mathrm{H}, \mathrm{m}, 2 \times \mathrm{ArH}) ; \delta_{\mathrm{C}}(100 \mathrm{MHz}) 16.56$ (7-Me), 24.75 (3a-Me), 34.09 (N-Me), 39.53 (3-C), 52.65 (6-C), 54.94 (7-C), 70.06 (3a-C), 93.58 (2-C), 128.86 (ArC), 129.46 (ArC), 134.42 (ArC), 137.44 (n-ArC), 168.52 (4-C). NOEDS results for 13b: irradiation of $3 \mathrm{a}-\mathrm{H}$ caused the following enhancements 3a-Me (1.6\%) and 2-H (3\%). Irradiation of 7-H caused the following enhancements $7-\mathrm{Me}(7 \%), 3 \mathrm{~b}-\mathrm{H} / 6 \mathrm{a}-\mathrm{H}$ $(10 \%) 3 \mathrm{a}-\mathrm{H}(-\mathrm{ve} \%)$. Irradiation of $3 \mathrm{a}-\mathrm{H}$ caused enhancements on $3 \mathrm{~b}-\mathrm{H} / 6 \mathrm{a}-\mathrm{H}(25 \%), 7-\mathrm{H}(-\mathrm{ve} \%)$ and $2-\mathrm{H}(11 \%)$.

\section{7-Methyl-3a-phenyl-2-(phenylsulfonyl)tetrahydro-2H-isoxazolo- [2,3-a]pyrazine-4(5H)-one $13 \mathrm{c}$}

A solution of nitrone $\mathbf{1 b}(0.05 \mathrm{~g}, 0.245 \mathrm{mmol})$ and phenyl vinyl sulfone $(0.05 \mathrm{~g}, 0.294 \mathrm{mmol})$ in toluene $\left(30 \mathrm{~cm}^{3}\right)$ under a nitrogen atmosphere was heated at reflux for $48 \mathrm{~h}$. The reaction mixture was allowed to cool to $\mathrm{rt}$ and the solvent removed under reduced pressure. Purification of the crude product by flash chromatography $\left(\mathrm{Et}_{2} \mathrm{O}\right.$-petroleum spirit, $\left.1: 2\right)$ afforded 13c $(58.7 \mathrm{mg}, 65 \%)$ and unreacted dipole $(16.2 \mathrm{mg}, 32 \%)$; 13c colourless plates, mp $193-194{ }^{\circ} \mathrm{C}$ (from $\mathrm{Et}_{2} \mathrm{O}$-petroleum spirit); $\delta_{\mathrm{H}}(400 \mathrm{MHz}) 1.39(3 \mathrm{H}, \mathrm{d}, J 5.5,7-\mathrm{Me}), 3.21(2 \mathrm{H}, \mathrm{m}, 6 \mathrm{a}-/ 6 \mathrm{~b}-\mathrm{H})$, $3.38(1 \mathrm{H}, \mathrm{dd}, J 13.5,9.5,3 \mathrm{~b}-\mathrm{H}), 3.52(1 \mathrm{H}, \mathrm{dd}, J 13.5,7.1,3 \mathrm{a}-\mathrm{H})$, $3.71(1 \mathrm{H}, \mathrm{m}, 7-\mathrm{H}), 4.68(1 \mathrm{H}, \mathrm{dd}, J 9.5,7.1,2-\mathrm{H}), 7.61(1 \mathrm{H}, \mathrm{br} \mathrm{s}$, $\mathrm{NH}), 7.31(3 \mathrm{H}, \mathrm{m}, o-, p-\mathrm{ArH}), 7.54\left(2 \mathrm{H}, \mathrm{m}, 2 \times \mathrm{ArH} \mathrm{SO}_{2} \mathrm{Ph}\right)$, $7.65\left(1 \mathrm{H}, \mathrm{m}, 1 \times \mathrm{ArH} \mathrm{SO}_{2} \mathrm{Ph}\right), 7.78(2 \mathrm{H}, \mathrm{m}, m-\mathrm{ArH}), 7.89(2 \mathrm{H}$, $\left.\mathrm{m}, 2 \times \mathrm{ArH} \mathrm{SO}_{2} \mathrm{Ph}\right) ; \delta_{\mathrm{C}}(100 \mathrm{MHz}) 16.62(+)(7-\mathrm{Me}), 39.08(-)$ (3-C), 45.16 (-) (6-C), 55.60 (+) (7-C), 74.75 (abs.) (3a-C), $92.71(+)(2-C), 127.06,128.29,128.80,129.35,134.32(+)$ (ArC), 137.21 (abs.) (n-ArC), 138.14 (abs.) (n-ArC), 169.69 (abs.) (4-C); NOEDS results for 13c: irradiation of $3 \mathrm{a}-\mathrm{H}$ caused the following enhancements $3 \mathrm{~b}-\mathrm{H}(1.6 \%), 2-\mathrm{H}(9 \%)$ and $7-\mathrm{H}$ $(-\mathrm{ve} \%)$. Irradiation of $7-\mathrm{H}$ caused the following enhancements 7-Me $(6 \%)$, 3b-H (5\%) 2-H (1\%) and 3a-H (-ve \%). Irradiation of $2-\mathrm{H}$ caused an enhancement on $3 \mathrm{a}-\mathrm{H}(4 \%)$.

Dimethyl 3a,7-dimethyl-4-oxo-4,5,6,7-tetrahydro-3a $H$-isoxazolo[2,3a]pyrazine-2,3-dicarboxylate 15a

Nitrone 1a $(0.30 \mathrm{~g}, 2.12 \mathrm{mmol})$ and dimethyl acetylene- dicarboxylate $(0.45 \mathrm{~g}, 3.18 \mathrm{mmol})$ were heated at reflux in $\mathrm{CHCl}_{3}$ $\left(50 \mathrm{~cm}^{3}\right)$ under a nitrogen atmosphere for $9 \mathrm{~h}$. The reaction mixture was allowed to cool to rt and the solvent was removed under reduced pressure. Analysis of the crude material by ${ }^{1} \mathrm{H}$ NMR spectral analysis showed a major adduct and three minor products in a $\sim 9: 2: 1: 1$ ratio. Purification of the crude material by flash chromatography $\left(\mathrm{Et}_{2} \mathrm{O}\right.$-petroleum spirit, $\left.1: 1\right)$ yielded 15a $(0.374 \mathrm{~g}, 63 \%)$; 15a, colourless needle-like crystals, mp 136.5-137. ${ }^{\circ} \mathrm{C}$ (from $\mathrm{CHCl}_{3}$ : hexane) (Found: $\mathrm{C}, 50.66 ; \mathrm{H}$, 5.75; N, 9.39. $\mathrm{C}_{12} \mathrm{H}_{16} \mathrm{O}_{6} \mathrm{~N}_{2}$ requires: $\mathrm{C}, 50.70 ; \mathrm{H}, 5.63 ; \mathrm{N}$, $9.86 \%) ; \delta_{\mathrm{H}}(400 \mathrm{MHz}) 1.28(3 \mathrm{H}, \mathrm{d}, J 6.2,7-\mathrm{Me}), 1.73(3 \mathrm{H}, \mathrm{s}, 3 \mathrm{a}-$ Me), $3.10(1 \mathrm{H}$, dd, $J 12.9,10.1,6 \mathrm{~b}-\mathrm{H}), 3.20(1 \mathrm{H}, \mathrm{ddd}, J 12.9$, 5.4, 3.9, 6a-H), $3.28(1 \mathrm{H}, \mathrm{m}, 7-\mathrm{H}), 3.81(3 \mathrm{H}, \mathrm{s}, \mathrm{OMe}), 3.83(3 \mathrm{H}$, s, OMe), $7.23(1 \mathrm{H}, \mathrm{d}, J 3.9, \mathrm{~N}-\mathrm{H},) ; \delta_{\mathrm{C}}(100 \mathrm{MHz}) 16.50(7-\mathrm{Me})$, 26.01 (3a-Me), 43.29 (6-C), 52.67 (OMe), 52.88 (OMe), 54.79 (7-C), 75.51 (3a-C), 118.74 (3-C), $143.62(2-\mathrm{C}), 158.27(\mathrm{C}=\mathrm{O})$, $162.89(\mathrm{C}=\mathrm{O}), 168.54(4-\mathrm{C}) ; \delta_{\mathrm{H}}\left(400 \mathrm{MHz}, \mathrm{C}_{6} \mathrm{D}_{6}\right) 0.92(3 \mathrm{H}, \mathrm{d}$, $J$ 6.2, 7-Me), 1.90 (3H, s, 3a-Me), 2.12 (1H, ddd, J 12.1, 3.7, 3.7, 6a-H), $2.33(1 \mathrm{H}, \mathrm{dd}, J 12.1,11.0,6 \mathrm{~b}-\mathrm{H}), 2.78(1 \mathrm{H}, \mathrm{m}, 7-\mathrm{H}), 3.21$ $(3 \mathrm{H}, \mathrm{s}, \mathrm{OMe}), 3.63(3 \mathrm{H}, \mathrm{s}, \mathrm{OMe}), 6.67(1 \mathrm{H}, \mathrm{br} \mathrm{s}, \mathrm{N}-\mathrm{H}) ; \delta_{\mathrm{C}}(100$ MHz) 16.28 (7-Me), 26.39 (3-Me), 42.74 (6-C), 51.82 (OMe), 52.08 (OMe), 54.67 (7-C), 75.64 (3a-C), 119.29 (3-C), 143.96 $(2-\mathrm{C}), 158.27(\mathrm{C}=\mathrm{O}), 162.77(\mathrm{C}=\mathrm{O}), 168.80(4-\mathrm{C}) ; v_{\max } / \mathrm{cm}^{-1}$ $3184(\mathrm{NH}), 1739,1732,1678$ and 1457. NOEDS results for 15a $\left(\mathrm{C}_{6} \mathrm{D}_{6}\right)$ : irradiation of $7-\mathrm{H}$ caused the following enhancements $7-\mathrm{Me}(5 \%)$ and $6 \mathrm{a}-\mathrm{H}(3 \%)$.

\section{Dimethyl 3a,5,7-trimethyl-4-oxo-4,5,6,7-tetrahydro-3a $\mathrm{H}$ - soxazolo[2,3-a]pyrazine-2,3-dicarboxylate $15 \mathrm{~b}$}

A solution of nitrone $1 \mathrm{c}(50 \mathrm{mg}, 0.32 \mathrm{mmol})$ and dimethyl acetylenedicarboxylate $(70 \mathrm{mg}, 0.48 \mathrm{mmol})$ in $\mathrm{CHCl}_{3}\left(5 \mathrm{~cm}^{3}\right)$ under a nitrogen atmosphere was heated at reflux for $24 \mathrm{~h}$. The mixture was allowed to cool to $\mathrm{rt}$ and solvent was removed under reduced pressure. ${ }^{1} \mathrm{H}$ NMR spectral analysis of the crude reaction mixture indicated one major cycloadduct and three minor products in approximately $10: 1: 1: 1$ ratio. Purification by flash chromatography $\left(\mathrm{Et}_{2} \mathrm{O} 100 \%\right)$ afforded a pure sample of $\mathbf{1 5 b}(63.6 \mathrm{mg}, 67 \%)$; orange cubic crystals, mp $117-119^{\circ} \mathrm{C}$ (from $\mathrm{CHCl}_{3}$-hexane) (Found: C, 52.28; H, 5.90; N, 9.30. 
$\mathrm{C}_{13} \mathrm{H}_{18} \mathrm{~N}_{2} \mathrm{O}_{6}$ requires: $\left.\mathrm{C}, 52.34 ; \mathrm{H}, 6.08 ; \mathrm{N}, 9.39 \%\right) ; \delta_{\mathrm{H}}(400$ MHz) $1.30(3 \mathrm{H}, \mathrm{d}, J$ 5.4, 7-Me), $1.74(3 \mathrm{H}, \mathrm{s}, 3 \mathrm{a}-\mathrm{Me}), 2.96(3 \mathrm{H}$, s, $\mathrm{N}-\mathrm{Me}), 3.08(1 \mathrm{H}, \mathrm{dd}, J 12.2,2.9,6 \mathrm{a}-\mathrm{H}), 3.26(1 \mathrm{H}, \mathrm{dd}, J 12.2$, 10.7, 6b-H), $3.32(1 \mathrm{H}, \mathrm{m}, 7-\mathrm{H}), 3.84(3 \mathrm{H}, \mathrm{s}, \mathrm{OMe}), 3.86(3 \mathrm{H}, \mathrm{s}$, $\mathrm{OMe}) ; \delta_{\mathrm{C}}(100 \mathrm{MHz}) 16.62(+)(7-\mathrm{Me}), 26.56(+)(3 \mathrm{a}-\mathrm{Me})$, $34.50(+)(\mathrm{N}-\mathrm{Me}), 50.89(-)(6-\mathrm{C}), 52.80,52.88(+)(2 \times \mathrm{OMe})$, 54.28 (+) (7-C), 76.07 (abs.) (3a-C), 119.54 (abs.) (3-C), 142.85 (abs.) (2-C), 158.31 and 163.28 (abs.) $\left(2 \times \mathrm{CO}_{2} \mathrm{Me}\right), 165.78$ (abs.) (4-C); NOEDS results for $\mathbf{1 5 b}$ : irradiation of $6 \mathrm{a}-\mathrm{H}$ caused the following enhancements $7-\mathrm{Me}(4 \%), 6 \mathrm{~b}-\mathrm{H}(30 \%)$.

\section{Dimethyl 7-methyl-4-oxo-3a-phenyl-4,5,6,7-tetrahydro-3a $\mathrm{H}$-iso-} xazolo[2,3- $a$ ]pyrazine-2,3-dicarboxylate $15 \mathrm{c}$ and $15 \mathrm{c}$

Nitrone 1b $(0.140 \mathrm{~g}, 0.676 \mathrm{mmol})$ and dimethyl acetylenedicarboxylate $(0.146 \mathrm{~g}, 1.03 \mathrm{mmol})$ in $\mathrm{CHCl}_{3}\left(18 \mathrm{~cm}^{3}\right)$ were stirred under a nitrogen atmosphere at $\mathrm{rt}$ for $40 \mathrm{~h}$. The reaction mixture was allowed to cool to rt and the solvent removed under reduced pressure. Analysis of the ${ }^{1} \mathrm{H}$ NMR spectral data indicated the presence of unreacted nitrone and two diastereomers of the cycloadduct in a $1.2: 6: 1$ ratio. Purification by flash chromatography $\left(\mathrm{Et}_{2} \mathrm{O}\right)$ afforded a pure sample of $\mathbf{1 5 c}(0.111 \mathrm{~g}$, $47 \%)$; its diastereomer $15 \mathbf{c}^{\prime}$ was obtained as a mixture $(1: 1.2)$ together with the major adduct $\mathbf{1 5 c}(0.065 \mathrm{~g}, 19 \%)$; 15c, colourless, cubic crystals, mp $158-160{ }^{\circ} \mathrm{C}$ (from $\mathrm{CHCl}_{3}$-hexane) (Found: C, 58.97; $\mathrm{H}, 5.40 ; \mathrm{N}, 8.40 . \mathrm{C}_{17} \mathrm{H}_{18} \mathrm{~N}_{2} \mathrm{O}_{6}$ requires: $\mathrm{C}$, $58.96 ; \mathrm{H}, 5.24 ; \mathrm{N}, 8.09 \%) ; \delta_{\mathrm{H}}(400 \mathrm{MHz}) 1.34(3 \mathrm{H}, \mathrm{d}, J 5.9$, 7-Me), 3.19 (2H, m, 6a/6b-H), 3.49 (1H, m, 7-H), 3.79 (3H, s, $\mathrm{OMe}), 3.86(3 \mathrm{H}, \mathrm{s}, \mathrm{OMe}), 6.84(1 \mathrm{H}$, br s, NH) $7.35(3 \mathrm{H}, \mathrm{m}, o-$, $p$-ArH), 7.69 (2H, m, m-ArH); $\delta_{\mathrm{C}}(100 \mathrm{MHz}) 16.85$ (7-Me), 43.47 (6-C), 52.81 (7-C), 53.11 (OMe), 56.68 (OMe), 77.14 (3a-C), 116.67 (3-C), 127.12 (ArC), 128.56 (ArC), 128.65 (ArC), 139.85 (n-ArC), 146.31 (2-C), $158.45(\mathrm{C}=\mathrm{O}), 163.04(\mathrm{C}=\mathrm{O})$, 167.49 (4-C); $m / z 347(\mathrm{M}+1)$.

$\mathbf{1 5} \mathbf{c}^{\prime}$ Obtained as an inseparable mixture with the major cycloadduct $15 \mathbf{c}$ identifiable signals that can be assigned to the minor diastereomer are: $\delta_{\mathrm{H}}(400 \mathrm{MHz}) 1.26(\mathrm{~d}, J 5.5,7-\mathrm{Me})$, 3.60 (s, OMe), 3.91 (s, OMe).

\section{Dimethyl 4-methyl-1-oxo-1,2,3,4-tetrahydropyrrolo [1,2-a] pyrazine-6,7-dicarboxylate $16 \mathrm{a}$}

Adduct 15a (50 mg, $0.176 \mathrm{mmol})$ was heated at reflux under a nitrogen atmosphere in $\mathrm{CHCl}_{3}\left(5 \mathrm{~cm}^{3}\right)$ for $24 \mathrm{~h}$. The mixture was allowed cool to $\mathrm{rt}$ and the solvent removed under reduced pressure. Purification by flash chromatography $\left(\mathrm{Et}_{2} \mathrm{O}\right)$ yielded 16a $(31 \mathrm{mg}, 66 \%)$; 16a, colourless, rectangular crystals, $\mathrm{mp}$ 154-156 ${ }^{\circ} \mathrm{C}$, (from $\mathrm{CHCl}_{3}$-hexane) $(\mathrm{C}, 53.94 ; \mathrm{H}, 5.62 ; \mathrm{N}$, 9.87. $\mathrm{C}_{12} \mathrm{H}_{14} \mathrm{~N}_{2} \mathrm{O}_{5}$ requires $\left.\mathrm{C}, 54.13 ; \mathrm{H}, 5.30 ; \mathrm{N}, 10.52 \%\right)$; $\delta_{\mathrm{H}}(400 \mathrm{MHz}) 1.50(3 \mathrm{H}, \mathrm{d}, J 6.8,4-\mathrm{Me}), 3.41(1 \mathrm{H}, \mathrm{dd}, J 12.5$, 4.6, 3a-H), $3.85(3 \mathrm{H}, \mathrm{s}, \mathrm{OMe}), 3.94(4 \mathrm{H}, \mathrm{s}, \mathrm{m}, \mathrm{OMe}, 3 \mathrm{~b}-\mathrm{H})$, $5.09(1 \mathrm{H}, \mathrm{m}, 4-\mathrm{H}), 7.02(1 \mathrm{H}$, br s, NH), $7.22(1 \mathrm{H}, \mathrm{s}, 8-\mathrm{H})$; $\delta_{\mathrm{C}}(100 \mathrm{MHz}) 19.53(+)(4-\mathrm{Me}), 45.52(-)(3-\mathrm{C}), 49.34(+)$ (4-C), $52.05(+)(\mathrm{OMe}), 52.52(+)(\mathrm{OMe}), 114.89(+)(8-\mathrm{C})$, 121.05 (abs.) (7-C), 124.57 (abs.) (8a-C), 125.76 (abs.) (6-C), 159.94 (abs.) (1-C), 161.00 (abs.) $\left(\mathrm{CO}_{2} \mathrm{Me}\right), 164.23$ (abs.) $\left(\mathrm{CO}_{2} \mathrm{Me}\right) ; \mathrm{m} / \mathrm{z} 266 \mathrm{M}^{+}$

\section{Dimethyl 2,4-dimethyl-1-oxo-1,2,3,4-tetrahydropyrrolo[1,2-a]- pyrazine-6,7-dicarboxylate $16 \mathrm{~b}$}

Adduct 15b (0.05 g, $0.168 \mathrm{mmol})$ was heated at reflux under a nitrogen atmosphere in $\mathrm{CHCl}_{3}\left(4.7 \mathrm{~cm}^{3}\right)$ for $72 \mathrm{~h}$. The mixture was allowed to cool to rt, concentrated and purified by flash column chromatography $\left(\mathrm{Et}_{2} \mathrm{O}\right)$ to afford $\mathbf{1 6 b}(0.04 \mathrm{~g}, 85 \%)$ and a mixture of decomposition products; $\mathbf{1 6} \mathbf{b}$, a viscous, brightyellow oil $\left(R_{\mathrm{f}} 0.096 \mathrm{Et}_{2} \mathrm{O}\right) ; \delta_{\mathrm{H}}(400 \mathrm{MHz}) 1.40(3 \mathrm{H}$, br d, 4-Me), $3.07(3 \mathrm{H}, \mathrm{s}, \mathrm{N}-\mathrm{Me}), 3.18(1 \mathrm{H}$, br d, 3a-H), 3.78 (3H, s, OMe), $3.84(3 \mathrm{H}, \mathrm{s}, \mathrm{OMe}), 3.94(1 \mathrm{H}, \mathrm{br} \mathrm{dd}, 3 \mathrm{~b}-\mathrm{H}), 5.02(1 \mathrm{H}, \mathrm{br} \mathrm{m}$, 4-H); DEPT 135 (400 MHz) 19.76 (4-Me), 34.26 (N-Me), 49.07 (4-C), $51.98(\mathrm{OMe}), 52.35(\mathrm{OMe}), 53.17$ (3-C), 114.52 (8-C);
GC-MS calculated for $\mathrm{C}_{13} \mathrm{H}_{16} \mathrm{~N}_{2} \mathrm{O}_{5}: 280.1059$. Found 280.1045 for $\mathrm{C}_{13} \mathrm{H}_{16} \mathrm{~N}_{2} \mathrm{O}_{5}$.

Methyl 3a,7-dimethyl-4-oxo-4,5,6,7, tetrahydro-3a $\mathrm{H}$ isoxazolo[2,3-a]pyrazine-2-carboxylate 21a and methyl 3a,7-dimethyl-4oxo-4,5,6,7, tetrahydro-3a $H$ isoxazolo[2,3-a]pyrazine-3carboxylate 22a

Nitrone 1a ( $0.20 \mathrm{~g}, 1.42 \mathrm{mmol})$ and methyl propiolate $(0.716 \mathrm{~g}$, $8.52 \mathrm{mmol}$ ) were stirred at $\mathrm{rt}$ under a nitrogen atmosphere for $7 \mathrm{~d}$. Unreacted dipolarophile was removed under reduced pressure and ${ }^{1} \mathrm{H}$ NMR analysis of the crude suggested two major isomeric cycloadducts in $1: 1.7$ ratio. Purification by column chromatography ( $\mathrm{Et}_{2} \mathrm{O}$-petroleum spirit; $\left.2: 1\right)$ afforded a pure sample of the 5-substituted isomer 21 a ( $72 \mathrm{mg}, 22 \%$ ), the 4-substituted isomer 22a could not be obtained pure (166 mg, $52 \%$ ); 21a, colourless cubic crystals, mp $116-118{ }^{\circ} \mathrm{C}$ (from $\mathrm{CHCl}_{3}$-hexane) (Found C, 53.21; H, 6.03; N, 12.38. $\mathrm{C}_{10} \mathrm{H}_{14^{-}}$ $\mathrm{N}_{2} \mathrm{O}_{4}$ requires C, 53.10; $\left.\mathrm{H}, 6.19 ; \mathrm{N}, 12.39 \%\right) ; \delta_{\mathrm{H}}(400 \mathrm{MHz}) 1.30$ $(3 \mathrm{H}, \mathrm{d}, J 5.5,7-\mathrm{Me}), 1.58(3 \mathrm{H}, \mathrm{s}, 3 \mathrm{a}-\mathrm{Me}), 3.20(3 \mathrm{H}, \mathrm{m}, 6 \mathrm{a} / 6 \mathrm{~b} /$ 7-H), $3.83(3 \mathrm{H}, \mathrm{s}, \mathrm{OMe}), 6.08(1 \mathrm{H}, \mathrm{s}, 3-\mathrm{H}), 6.93(1 \mathrm{H}, \mathrm{br}, \mathrm{NH})$; $\delta_{\mathrm{H}}(400 \mathrm{MHz})\left(\mathrm{C}_{6} \mathrm{D}_{6}\right) 0.97(3 \mathrm{H}, \mathrm{d}, J 6.2,7-\mathrm{Me}), 1.62(3 \mathrm{H}, \mathrm{s}, 3 \mathrm{a}-$ $\mathrm{Me}), 2.21(1 \mathrm{H}, \mathrm{m}, 6 \mathrm{a}-\mathrm{H}), 2.46(1 \mathrm{H}$, sl. br dd, 6b-H), $2.72(1 \mathrm{H}$, $\mathrm{m}, 7-\mathrm{H}), 3.25(3 \mathrm{H}, \mathrm{s}, \mathrm{OMe}), 6.25(1 \mathrm{H}, \mathrm{s}, 3-\mathrm{H}), 7.60(1 \mathrm{H}, \mathrm{br}$, $\mathrm{NH}) ; \delta_{\mathrm{C}}(100 \mathrm{MHz}) 16.90(+)(7-\mathrm{Me}), 26.71(+)(3-\mathrm{Me}), 43.52$ $(-)(6-\mathrm{C}), 52.48(+)(7-\mathrm{C}), 54.73(+)(\mathrm{OMe}), 74.22$ (abs.) (3a-C), 114.43 (+) (3-C), 144.53 (abs.) (2-C), 159.39 (abs.) $(\mathrm{C}=$ O), 170.22 (abs.) (4-C). NOEDS results for $21 a\left(\mathrm{C}_{6} \mathrm{D}_{6}\right)$ irradiation of $3 \mathrm{a}-\mathrm{Me}$ caused the following enhancements $6 \mathrm{a}-\mathrm{H}$ $(0.4 \%), 6 \mathrm{~b}-\mathrm{H}(0.4 \%), 7-\mathrm{H}(0.5 \%)$ and $3-\mathrm{H}(1.5 \%)$. Irradiation of $6 \mathrm{a}-\mathrm{H}$ caused the following enhancements $7-\mathrm{H}(8 \%)$ and $6 \mathrm{~b}-\mathrm{H}$ $(21 \%)$. Irradiation of $6 \mathrm{~b}-\mathrm{H}$ caused enhancements on $7-\mathrm{Me}(3 \%)$ and $6 \mathrm{a}-\mathrm{H}(15 \%)$; 22a, a brown powder, $\mathrm{mp} 109-112{ }^{\circ} \mathrm{C}$ (from $\mathrm{CHCl}_{3}$-hexane) (Found $\mathrm{C}, 52.75 ; \mathrm{H}, 6.13 ; \mathrm{N}, 12.19 . \mathrm{C}_{10} \mathrm{H}_{14^{-}}$ $\mathrm{N}_{2} \mathrm{O}_{4}$ requires C, 53.10; $\left.\mathrm{H}, 6.19 ; \mathrm{N}, 12.39 \%\right) ; \delta_{\mathrm{H}}(400 \mathrm{MHz}) 1.25$ $(3 \mathrm{H}, \mathrm{d}, J 6.6,7-\mathrm{Me}), 1.73(3 \mathrm{H}, \mathrm{s}, 3 \mathrm{a}-\mathrm{Me}), 3.13(1 \mathrm{H}, \mathrm{m}, 6 \mathrm{a}-\mathrm{H})$, $3.42(2 \mathrm{H}, \mathrm{m}, 6 \mathrm{~b}, 7-\mathrm{H}), 3.71(3 \mathrm{H}, \mathrm{s}, \mathrm{OMe}), 7.08(1 \mathrm{H}, \mathrm{br}, \mathrm{NH})$, $7.39(1 \mathrm{H}, \mathrm{s}, 2-\mathrm{H})$.

Methyl 7-methyl-4-oxo-3a-phenyl-4,5,6,7-tetrahydro-3a $H$ isoxazolo[2,3-a]pyrazine-2-carboxylates $21 \mathrm{~b}, 21 \mathrm{~b}^{\prime}$, and methyl 7-methyl-4-oxo-3a-phenyl-4,5,6,7-tetrahydro-3a $\mathrm{H}$-isoxazolo[2,3-a]pyrazine-3-carboxylates 22b

Nitrone 1b (100 mg, $0.490 \mathrm{mmol})$ and methyl propiolate (200 mg, $2.45 \mathrm{mmol})$ were heated at reflux in $\mathrm{CHCl}_{3}\left(14 \mathrm{~cm}^{3}\right)$ under a nitrogen atmosphere for $42 \mathrm{~h}$. The mixture was allowed to cool to $\mathrm{rt}$ and the solvent removed under reduced pressure. ${ }^{1} \mathrm{H}$ NMR spectral analysis of crude reaction product showed unreacted nitrone and two major cycloadducts the 5-substituted isoxazoline 21b and the 4-substituted isoxazoline 22b in approximately a $1: 1$ ratio. A number of minor products including a second diastereomer of the 5-substitued isoxazoline $\mathbf{2 1 \mathbf { b } ^ { \prime }}$ were present. Purification by flash column chromatography $\left(\mathrm{Et}_{2} \mathrm{O}\right)$ afforded a pure sample of the $\mathbf{2 1 b}(44 \mathrm{mg}, 31 \%)$ as well as samples of $\mathbf{2 1 \mathbf { b } ^ { \prime }}$ (7 $\mathrm{mg}, 5 \%$ ) and 22b (51 mg, 36\%); 21b, colourless cubic crystals, mp $172-174{ }^{\circ} \mathrm{C}\left(\mathrm{Et}_{2} \mathrm{O}\right.$-petroleum spirit) (Found: $\mathrm{H}, 62.30 ; \mathrm{H}, 5.36 ; \mathrm{N}, 9.77 . \mathrm{C}_{15} \mathrm{H}_{16} \mathrm{~N}_{2} \mathrm{O}_{4}$ requires: C, 62.49; H, 5.59; N, 9.72\%); $\delta_{\mathrm{H}}(400 \mathrm{MHz}) 1.39(3 \mathrm{H}, \mathrm{d}, J$ 5.9, 7-Me), $3.22(1 \mathrm{H}, \mathrm{m}, 7-\mathrm{H}), 3.40(2 \mathrm{H}, \mathrm{m}, 6 \mathrm{a} / 6 \mathrm{~b}-\mathrm{H}), 3.82(3 \mathrm{H}, \mathrm{s}$, OMe), $6.41(1 \mathrm{H}, \mathrm{s}, 3-\mathrm{H}), 7.01(1 \mathrm{H}$, br s, NH), $7.32(3 \mathrm{H}, \mathrm{m}, o-$, $p$-ArH), $7.65(2 \mathrm{H}, \mathrm{m}, m-\mathrm{ArH}) ; \delta_{\mathrm{C}}(100 \mathrm{MHz}) 17.18(+)(7-\mathrm{Me})$, 43.42 (-) (6-C), $52.46(+)$ (7-C), 56.49 (+) (OMe), 79.59 (abs.) (3a-C), $112.54(+)(3-\mathrm{C}), 126.46(+)$ (ArC), 128.25 (+) (ArC), 128.55 (+) (ArC), 141.20 (abs.) (2-C), 144.98 (abs.) (n-ArC), 160.43 (abs.) (C=O), 169.01 (abs.) (4-C). X-Ray crystal determination of 21b as per compound 11c. Crystal data $\dagger$ for $\mathbf{2 1 b}$, see Table $3 ; \mathbf{2 1}^{\prime}$ obtained as an inseparable mixture with 21b identifiable signals that can be assigned to the minor diastereomer are: $\delta_{\mathrm{H}}(400 \mathrm{MHz}) 1.39(\mathrm{~d}, J$ 5.9, 7-Me), 3.23 $(\mathrm{m}, 6 \mathrm{a}-\mathrm{H}), 3.63(\mathrm{~m}, 6 \mathrm{~b}-\mathrm{H}), 3.82$ (s, OMe), 6.43 (s, 3-H); 22b, 
Table 3 Crystal data and structure refinement for $\mathbf{2 1 b}$

$\begin{array}{ll}\text { Identification code } & \text { jf } 9 \\ \text { Empirical formula } & \mathrm{C}_{15} \mathrm{H}_{16} \mathrm{~N}_{2} \mathrm{O}_{4} \\ \text { Formula weight } & 288.30 \\ \text { Temperature } & 298(2) \mathrm{K} \\ \text { Wavelength } & 0.71069 \AA \\ \text { Crystal system } & \text { Orthorhombic } \\ \text { Space group } & \mathrm{Pbca} \\ \text { Unit cell dimensions } & a=8.4604(16) \AA \\ & b=19.740(2) \AA \\ \text { Volume } & c=16.800(2) \AA \\ Z & 2805.7(7) \AA^{3} \\ \text { Density (calculated) } & 8 \\ \text { Absorption coefficient } & 1.365 \mathrm{Mg} \mathrm{m}^{-3} \\ F(000) & 0.100 \mathrm{~mm}^{-1} \\ \text { Crystal size } & 1216 \\ \text { Theta range for data collection } & 0.44 \times 0.31 \times 0.27 \mathrm{~mm} \\ \text { Index ranges } & 2.06 \text { to } 20.88^{\circ} . \\ \text { Reflections collected } & -8<=h<=8 ;-19<=k<=19 ;-16<=l<=16 \\ \text { Independent reflections } & 7213 \\ \text { Reflections observed }(>2 \sigma) & 1459[R(\text { int })=0.0365] \\ \text { Data Completeness } & 1311 \\ \text { Max and min transmission } & 0.986 \\ \text { Refinement method } & 0.9732 \text { and } 0.9570 \\ \text { Data/restraints/parameters } & \text { Full-matrix least-squares on } F^{2} \\ \text { Goodness-of-fit on } \mathrm{F}^{2} & 1459 / 0 / 196 \\ \text { Final } R \text { indices }[I>2 \sigma(I)] & 1.026 \\ R \text { indices (all data) } & R_{1}=0.0435 \mathrm{w} R_{2}=0.1055 \\ \text { Largest diff. peak and hole } & R_{1}=0.0488 \mathrm{w} R_{2}=0.1105 \\ & 0.227 \text { and }-0.244 \mathrm{e} \AA \AA^{-3}\end{array}$

$R$ indices; $\left.R_{1}=\left[\Sigma|| F_{\mathrm{o}}|-| F_{\mathrm{c}} \mid\right] \mid\right] / \Sigma\left|F_{\mathrm{o}}\right|($ based on $F)$, w $R_{2}=\left[\left[\Sigma_{\mathrm{w}}\left(\left|F_{\mathrm{o}}{ }^{2}-F_{\mathrm{c}}{ }^{2}\right|\right)^{2}\right] /\left[\Sigma_{\mathrm{w}}\left(F_{\mathrm{o}}{ }^{2}\right)^{2}\right]\right]^{1 / 2}\left(\right.$ based on $\left.F^{2}\right) . \mathrm{w}=1 /\left[\left(\sigma F_{\mathrm{o}}\right)^{2}+\left(0.0712^{*} \mathrm{P}\right)^{2}+1.32^{*} \mathrm{P}\right]$. Goodness-of-fit $=\left[\Sigma_{\mathrm{w}}\left(F_{\mathrm{o}}{ }^{2}-F_{\mathrm{c}}\right)^{2} /(\text { Nobs }-N \text { parameters })\right]^{1 / 2}$.

a non-mobile brown oil (Found: H, 62.50; H, 5.59; N, 9.69. $\mathrm{C}_{15} \mathrm{H}_{16} \mathrm{~N}_{2} \mathrm{O}_{4}$ requires: $\left.\mathrm{C}, 62.49 ; \mathrm{H}, 5.59 ; \mathrm{N}, 9.72 \%\right) ; \delta_{\mathrm{H}}(400$ $\mathrm{MHz}) 1.24(3 \mathrm{H}, \mathrm{d}, J 5.9,7-\mathrm{Me}), 2.82(1 \mathrm{H}, \mathrm{m}, 6 \mathrm{a}-\mathrm{H}), 3.14(1 \mathrm{H}$, $\mathrm{m}, 6 \mathrm{~b}-\mathrm{H}), 3.42(1 \mathrm{H}, \mathrm{m}, 7-\mathrm{H}), 3.59(3 \mathrm{H}, \mathrm{s}, \mathrm{OMe}), 7.29(3 \mathrm{H}, \mathrm{m}$, $3 \times \mathrm{ArH}), 7.46(1 \mathrm{H}, \mathrm{s}, 2-\mathrm{H}), 7.62(2 \mathrm{H}, \mathrm{m}, 2 \times \mathrm{ArH}), 7.82(1 \mathrm{H}, \mathrm{br}$ $\mathrm{s}, \mathrm{NH})$.

\section{Acknowledgements}

This work has been supported by an Enterprise Ireland Postgraduate Award [JF], and the chemistry departments of The National University of Ireland, Galway and The National University of Ireland, Maynooth.

\section{References}

1 R. C. Bernotas and G. Adams, Tetrahedron Lett., 1996, 37, 7343.

2 R. C. Bernotas and G. Adams, Tetrahedron Lett., 1996, 37, 7339 .

3 M. Mano, T. Seo and K. Imai, Chem. Pharm. Bull., 1980, 28, 2720 .

4 K. Shinhama, K. Matoba, Y. Torisawa and J.-i. Minamikawa, Tetrahedron, 2000, 56, 7427.

5 M. I. M. Wazeer, H. P. Perzanowski, S. I. Qureshi, M. B. Al-Murad and S. A. Ali, Tetrahedron, 2000, 56, 7229.

6 B. Hinzen and S. V. Ley, J. Chem. Soc., Perkin Trans. 1, 1998, 1.

7 C. O'Mahony and F. Heaney, Chem. Commun., 1996, 167.

8 F. Heaney and C. O’Mahony, J. Chem. Soc., Perkin Trans. 1, 1998, 341.
9 A. V. Prosyanik, T. Z. Zorin, A. I. Mishchenko, V. M. Negrimovskii and A. B. Zolotoi, Izv. Akad. Nauk SSSR, Ser. Khim., 1985, 1840.

10 C. Bischoff and E. Schroeder, J. Prakt. Chem., 1988, 330, 379.

11 H. C. J. Ottenheum and J. H. M. de Man, Synthesis, 1975, 163.

12 A. Wawer, I. Wawer, B. Piekarska-Bartoszewicz and A. Temeriusz, Spectrosc. Lett., 1996, 29, 1079.

13 A. V. Afonin, I. A. Ushakov, O. A. Tarasova, E. Y. Shmidt, A. I. Mikhaleva and V. K. Voronov, Russ. J. Org. Chem. (Trans. Zh. Org. Khim. ), 2000, 36, 1777.

14 R. D. Bach, I. Mintcheva, W. J. Kronenberg and H. B. Schlegel, J. Am. Chem. Soc., 1993, 58, 6135 .

15 P. J. Dunn, A. B. Graham, R. Grigg, P. Higginson and I. S. Saba, Chem. Commun., 2000, 2033.

16 R. N. Ring, G. C. Tesoro and D. R. Moore, J. Org. Chem., 1967, 32, 1091.

17 I. B. Abdrakhmanov, N. A. Akmanova, G. B. Shabaeva and K. F. Sagitdinova, Izv. Vyssh. Uchebn. Zaved. Khim. Khim. Technol., 1985, 28, 29.

18 P. McArdle, J. Appl. Crystallogr., 1995, 28, 65.

19 G. M. Sheldrick, Acta. Crystallogr., Sect. A: Fundam. Crystallogr., 1990, 46, 467.

20 G. M. Sheldrick, SHELXL-97, a computer programme for crystal structure determinatiom, University of Gottingen, 1997.

21 F. Heaney, J. Fenlon, C. O'Mahony, P. McArdle and D. Cunningham, J. Chem. Soc., Perkin Trans. 1, 2001, 3382.

22 M. A. Brimble and D. D. Rowan, J. Chem. Soc., Chem. Commun., $1988,978$.

23 M. G. Banwell, A. M. Bray, A. C. Willis and D. J. Wong, New J. Chem., 1999, 23, 687.

24 A. C. B. Sosa, K. Yakushijin and D. A. Horne, Tetrahedron Lett., 2000, 41, 4295.

25 O. N. Tembo, P. Dallemagne, S. Rault and M. Robba, Heterocycles, 1993, 36, 2129. 